\title{
Role of Magnesium in Cardiac Disease
}

\author{
By H. Ebel
}

Institut für Klinische Physiologie, Klinikum Steglitz and

\section{T. Günther}

Institut für Molekularbiologie und Biochemie

\section{Freie Universität Berlin}

(Received July 9/December 21,1982 )

Summary: Some aspects of the pathogenesis of cardiac disease are reviewed in the light of current knowledge of the physiological and biochemical actions of magnesium $\left(\mathrm{Mg}^{2+}\right)$ on heart function. Several authors have reported a reduction of the human myocardial $\mathrm{Mg}^{2+}$ content in areas with $\left(\mathrm{Mg}^{2+}\right.$ poor) soft water, without a significant alteration of $\mathrm{Mg}^{2+}$ in serum or skeletal muscle. In human during myocardial infarction, there is a reduction of $\mathrm{Mg}^{2+}$ content even in noninfarcted areas of the myocardium, followed by a transient reduction of serum $\mathrm{Mg}^{2+}$ concentration. These effects are explained by the action of catecholamines on the myocardial cells, resulting in a loss of $\mathrm{Mg}^{2+}$ accompanied by a catecholamine-induced urinary $\mathrm{Mg}^{2+}$ loss and/or increased lipolysis which binds $\mathrm{Mg}^{2+}$ as $\mathbf{M g}^{2+}$ soaps in the adipocytes. As a consequence serum $\mathbf{M g}^{2+}$ may be decreased. A reduced serum $\mathrm{Mg}^{2+}$ concentration may enhance the action of catecholamines on the heart muscle as well as the action of vasopressive hormones, thus provoking contraction of coronary artery smooth muscle cells and favouring the development of arrhythmia.

\section{Die Rolle von Magnesium bei Herzerkrankungen}

Zusammenfassung: Aus der gegenwärtigen Kenntnis der physiologischen und biochemischen Wirkungen des Magnesiums $\left(\mathrm{Mg}^{2+}\right)$ auf das Herž werden einige Aspekte der Pathogenese von Herzkrankheiten referiert. Verschiedene Autoren fanden bei Menschen in Gegenden mit weichem ( $\mathrm{Mg}^{2+}$-armem) Trinkwasser eine Abnahme des $\mathrm{Mg}^{2+}$-Gehaltes im Myocard ohne signifikante Änderungen des $\mathbf{M g}^{2+}$-Gehaltes im Serum und Skelettmuskel. Die Bedeutung dièser Befunde bleibt ungeklärt. Bei Patienten kommt es während eines Myocardinfarktes im Myocard auch in den nichtinfarzierten Bereichen zu einer Abnahme des $\mathbf{M g}^{2+}-G_{\text {Gehaltes und }}$ im Serum zuu einer vorübergehenden Abnahme der $\mathrm{Mg}^{2+}$-Konzentration.

Diese Wirkungen lassen sich mit einer Katecholamin-bedingten $\mathrm{Mg}^{2+}$-Abgabe aụs den Myocardzellen erklären. Die Abnahme der $\mathrm{Mg}^{2+}$-Konzentration im Serum wird auf eine Katecholamin-bedingte vermehrte $\mathrm{Mg}^{2+}$-Ausscheidung durch die Niere und/oder eine vermehrte $\mathrm{Mg}^{2+}$-Aufnahme in Adipocyten zurückgeführt. Durch die vermehrte Lipolyse kann $\mathrm{Mg}^{2+}$ vorübergehend an freie Fettsäuren in Adipocyten gebunden werden. Bei einer verminderten $\mathbf{M g}^{2+}=$ Konzentration im Serum kann die Wirkung von Katecholaminen und vasopressiven Hormonen auf das Herż verstärkt werden. Dies kann eine Kontraktion der Koronararterien hervorrufen und das Auftreten einer Arrhythmie begünstigen. 


\section{Introduction}

Magnesium $\left(\mathrm{Mg}^{2+}\right)$ is the second most common intracellular cation. It is known to activate nearly 300 enzymes. By reacting with phospholipids, nucleic acids and cell membranes $\mathrm{Mg}^{2+}$ influences their structure and stability. By direct action via $\mathrm{Mg}^{2+} \mathrm{de}-$ pendent enzymes and ATP and by indirect effects via alteration of $\mathrm{Ca}^{2+}$ influx, $\mathrm{Mg}^{2+}$ modulates the tension development in skeletal, smooth and cardiac muscle.

In the last decade several reviews have been concerned with the relevance of $\mathrm{Mg}^{2+}$ in cardiac disease $(1-7)$. Nevertheless, the role of $\mathrm{Mg}^{2+}$ qualitively and quantitatively is not fully appreciated by most physicians, while some are inclined to overemphasize its importance. Despite the ready availability of serum $\mathrm{Mg}^{2+}$ determinations e.g. by atomic absorption spectrophotometry, such measurements are not routinely performed. The consequence is that essential data are often lacking. The aim of the present review is to elucidate some physiological and biochemical actions of $\mathrm{Mg}^{2+}$ in the mechanism of cardiac disease.

\section{Possible Effect of $\mathbf{M g}^{2+}$ Intake from Tap Water on Cardiovascular Disease}

In epidemiological studies, it has been suggested that there is a relationship between water hardness of local supplies and mortality rates from cardiovascular diseases. Since the early 1960 s several authors have established a negative correlation between water hardness and myocardial infarction (8-16). However, the correlation coefficients, although statistically significant, were small. Subsequent reviews of the principal epidemiological studies revealed that in approximately 30 to $50 \%$ of the papers such a relationship could not be detected $(16,17)$. This is not surprising, if one realizes

1) that some water analyses were made only at the waterworks and not at the user's tap where results can be quite different due to contact with conduit materials of the distributing network; also

2) the same hardness can be caused by differing proportions of $\mathrm{Ca}^{2+}$ and $\mathrm{Mg}^{2+}$; moreover,

3 ) deaths were registered at the place of residence, and exposure at the place of work, where large quantities of different drinking water may be consumed, was not taken into consideration.

It should be recognized that the soft water effect is not necessarily a cardio-specific one. It has been reported that the prevalence of cerebrovascular dis- eases (9), of bronchitis and infant or adult mortality $(12,18)$ were higher in soft than in hard water regions. Furthermore, the prevalence at birth of congenital malformations of the central nervous system was negatively correlated with total water hardness (19).

In Europe cardiovascular diseases tend to increase from south to north while water hardness decreases in the same direction $(12,20)$. In the USA incidence of cardiovascular disease and water hardness are lowest in the northern and midwest plains and highest in the southeast (20). It is clear that latitude per se is not the factor responsible for the rate of myocardial infarction. Perhaps some of the discrepancies in investigations of water hảrdiness and mortality from myocardial diseases may be attributed to a genetic factor since there is a strong correlation between blood group 0 and cardiovascular mortality (21).

Several authors have favored $\mathrm{Mg}^{2+}$ as the cardioprotective water factor $(2,15,16)$ and emphasized the importance of the $\mathrm{Ca}^{2+} / \mathrm{Mg}^{2+}$ ratio in food (14). In some presentations, the main argument is that

1) chronic $\mathrm{Mg}^{2+}$ deficient rats develop multiple focal cardiac necroses $(22-24)$ and

2) data have been presented showing that, generally in our western world the $\mathrm{Mg}^{2+}$ content of refined food is lower than in more primitive agricultural societies $(2,15)$.

When the individual $\mathrm{Mg}^{2+}$ intake from food is low, e.g. $200-250 \mathrm{mg}$, then the additional daily $\mathrm{Mg}^{2+}$ intake in $\mathrm{Mg}^{2+}$ rich, hard water regions, e.g. $50 \mathrm{mg}$, may have a "cardioprotective" effect while in soft water regions a chronic $\mathrm{Mg}^{2+}$ deficiency is likely to develop $(2,14,16,25)$. Unfortunately, it is difficult to evaluate the true human requirement of $\mathrm{Mg}^{2+}$ : depending on age and protein intake the values given by various authors range from 0.1 to $0.4 \mathrm{mmol} / \mathrm{kg}$ per day $(26,27)$. This may be partially due to consid= erable individual variation in intestinal absorption and renal excretion of $\mathrm{Mg}^{2+}$. For instance, patients with tetanic syndrome and normal $\mathrm{Mg}^{2+}$ intake via food and tap water were cured only when reçèiving an additional $200-600 \mathrm{mg} \mathrm{Mg}^{2+}$, which increased serum $\mathrm{Mg}^{2+}$ by approximately $10 \%$ (28).

To proof the soft water $\mathrm{Mg}^{2+}$ deficiency theory, serum levels of $\mathrm{Mg}^{2+}$ of a representative population of soft water and hard water regions should be compared. Only one study was concerned with this question. No difference in serum $\mathrm{Mg}^{2+}$ and $\mathrm{Ca}^{2+}$ was found for both populations. Also, bone mineralization measured by X-rays was the same (29). This finding is not very surprising, because the standard 
deviation of $\mathrm{Mg}^{2+}$ determinations makes it difficult to detect a decrease from the normal level in the range of $<10 \%$ as is the case in mild $\mathrm{Mg}^{2+}$ deficiency. The broad variation of normal serum $\mathrm{Mg}^{2+}$ levels may be caused not only by individual variation in intake and intestinal absorption but also by variation in exposure to stress. For example in man and rats, noise stress rapidly changes serum $\mathbf{M g}^{2+}$ concentration (30). Thus, comparison of serum $\mathrm{Mg}^{2+}$ in epidemiological studies of populations from soft and hard water areas is of limited value (see below).

In growing young rats with chronic $\mathrm{Mg}^{2+}$ deficiency cardiac $\mathrm{Mg}^{2+}$ is lower than in normally fed rats of the same age. However, this effect is only significant when serum $\mathrm{Mg}^{2+}$ is reduced below a threshold concentration of $0.6-0.7 \mathrm{mmol} / \mathrm{l}(31)$. Nevertheless, in humans some evidence in favour of the soft water $\mathrm{Mg}^{2+}$ deficiency theory might come from analysis of postmortem cardiac $\mathrm{Mg}^{2+}$ content of subjects who were residents in $\mathrm{Mg}^{2+}$ rich, hard water localities or $\mathrm{Mg}^{2+}$ poor, soft water regions. In a Canadian study cardiac tissue of victims from accidental death was analysed in order to compare residents in regions with either $29.4 \mathrm{ppm}$ or $2.8 \mathrm{ppm} \mathrm{Mg}^{2+}$ in tap water. As can be seen in table 1 it was found that in the soft water regions cardiac $\mathrm{Mg}^{2+}$ was $7 \%$ lower than in the hard water regions (36). Also in accidental death the $\mathrm{Mg}^{2+}$ content of coronary arteries was lower in soft water regions (11). One wonders why $\mathrm{Mg}^{2+}$ in heart muscle or coronary arteries is reduced in soft water regions while there is no reduction in serum $\mathrm{Mg}^{2+}$ concentration (see above). Evidence has been presented, that in some patients there may be a decrease in skeletal muscle $\mathbf{M g}^{2+}$, while the serum $\mathbf{M g}^{2+}$ value is normal $(43,44)$. However, in these analyses collagen was not determined in the sample. An apparently opposite result was reported in another study from England. Here water hardness was determined mainly by $\mathrm{Ca}^{2+}$, while the $\mathrm{Mg}^{2+}$ content of tap water was $5 \mathrm{mg} / \mathrm{l}$ and $2 \mathrm{mg} / 1$ respectively, which does not greatly affect the $\mathbf{M g}^{\dot{2}+}$ intake from water. Under this condition the $\mathrm{Mg}^{2+}$ content of cardiac tissue from soft water was $15-26 \%$ higher when compared with hard water $(37,45)$. On the other hand, in a studdy from the same country, using a large number of samples from 28 areas there was no evidence of any association between the tissue levels and the levels of $\mathrm{Mg}^{2+}$ and $\mathrm{Ca}^{2+}$ in tap water (41). This discrepancy cannot be explained.

In summary the soft water $\mathrm{Mg}^{2+}$ deficiency theory remains a rather unsettled issue. When $\mathrm{Mg}^{2+}$ intake by food is low, due to individual eating and cooking habits, then the $\mathrm{Mg}^{2+}$ content of drinking water may be critical in preventing a chronic low grade deficiency.

J. Clin. Chem. Clin. Biochem. / Vol. 21, 1983 / No. 5
$\mathrm{Mg}^{2+}$ Content of Heart Muscle after Myocardial Infarction

In dogs 8-11 hours after permanent coronary ligation the $\mathrm{Mg}^{2+}$ and $\mathrm{K}^{+}$content of the left infarcted ventricle were reduced by approximately $49 \%$ and $47 \%$ respectively. In the right non-infarcted ventricle the decrease of $\mathrm{Mg}^{2+}$ and $\mathrm{K}^{+}$were in the range of only $7 \%$ and $2 \%$, respectively, which was not significant (46). In similar experiments with rats, 24 hours after coronary ligation the $\mathrm{Mg}^{2+}$ and $\mathrm{K}^{+}$content of the injured region was reduced by $50 \%$ and $45 \%$, respectively while there was no change in the remaining healthy myocardium (24). In another study with coronary ligated dogs only the cation changes of the necrotic area were reported. Within one hour, the $\mathrm{Mg}^{2+}$ content dropped by $23 \%$ and remained constant at this level over the next hours (47). Also, after a period of 3 hours of experimental haemorrhagic hypotension of dogs the $\mathrm{Mg}^{2+}$ content of the right and left ventricular myocardium was lowered by $27 \%$ and $30 \%$ respectively (48). Furthermore, in asphyxic hearts of guinea pigs, the $\mathrm{Mg}^{2+}$ content was reduced by $31 \%$ compared with control hearts after one hour (49). In another type of experiment, using dogs, the effect of transient ischaemia followed by reperfusion was investigated; again there was no change in cellular $\mathrm{Mg}^{2+}$ and $\mathrm{Ca}^{2+}$ of the uninvolved tissue. In the infarcted posterior papillary muscle a $23 \%$ fall of $\mathrm{Mg}^{2+}$ and a more than 10 fold decrease of $\mathrm{Ca}^{2+}$ was registered (50).

The $\mathrm{Mg}^{2+}$ content of normal human heart determined by several authors is in the range of 200 $\mathrm{mg} / \mathrm{kg}$ wet weight (tab. 1 ). Table 2 shows the relative changes in the concentrations of $\mathrm{Mg}^{2+}, \mathrm{K}^{+}$and $\mathrm{Ca}^{2+}$ in patients who died of myocardial infarction, as verified by post-mortem examination. Essentially the same changes were found as obtained in experimental infarction with animals. However, in contrast to studies with experimental animals the electrolyte content of the remaining healthy regions of the human heart was also changed. The $\mathrm{Mg}^{2+}$ and $\mathrm{K}^{+}$content of the noninfarcted tissue was reduced $(3,34-$ $36,39-42)$ and that of $\mathrm{Ca}^{2+}$ was increased $(36,39$, $41,42)$. The percent $\mathrm{Mg}^{2+}$ loss of the uninfarcted left ventricle varied between $12 \%$ and $33 \%$. Ignoring the fact that the authors used different reference points, it can be said that in the 8 cited studies with 653 cases the average decrease of $\mathrm{Mg}^{2+}$ in the noninfarcted region of the left ventricle and apex was about $18 \%$.

In the infarcted necrotic areas the decrease of myocardial $\mathrm{Mg}^{2+}$ was more pronounced (42). The loss of $\mathrm{Mg}^{2+}$ from noninfarcted areas has been termed 
Tab. 1. Postmortal $\mathrm{Mg}^{2+}$ concentration in normal human heart.

Abbreviations: $L V=$ left ventricle, $R V=$ right ventricle, $V=$ ventricular, $A=$ apex, d.w. $=$ dry weight, w. $w .=$ wet weight, $\mathrm{n}=$ number of determinations.

* calculated from original data given in Eq or in Mol.

\begin{tabular}{|c|c|c|c|c|c|c|}
\hline Authors & Ref. & $\begin{array}{l}\text { Water- } \\
\text { hardness }\end{array}$ & $\begin{array}{l}\text { Locali- } \\
\text { sation }\end{array}$ & Dimension & Mean $\pm S D$ & $\mathbf{n}$ \\
\hline Iseri et al. & 32 & $?$ & LV & mg/kg w. w. & $54 \pm 7 *$ & 13 \\
\hline Meister \& Schumann & 33 & $?$ & $\begin{array}{l}\text { LV } \\
\text { RV }\end{array}$ & $\mathrm{mg} / \mathrm{kg} \mathbf{w w}$. & $\begin{array}{l}192 \pm 3.7 \\
180 \pm\end{array}$ & 26 \\
\hline Behr \& Burion & 34 & $?$ & $?$ & mg/kg w.w. & $216 \pm 38.5$ & 74 \\
\hline Chipperfield \& Chipperfield & 35 & $?$ & $?$ & mg/kg w.w. & $205 \pm 33$ & 19 . \\
\hline Anderson et al. & 36 & $\begin{array}{l}\text { hard } \\
\text { soft }\end{array}$ & A & $\mathrm{mg} / \mathrm{kg}$ d.w. & $\begin{array}{l}982 \pm 23 \\
918 \pm 15\end{array}$ & $\begin{array}{l}29 \\
54\end{array}$ \\
\hline Chipperfield \& Chipperfield & 37 & $\begin{array}{l}\text { hard } \\
\text { soft }\end{array}$ & V & mg/kg w.w. & $\begin{array}{l}174 \pm 23 \\
219 \pm 16\end{array}$ & $\begin{array}{l}12 \\
12\end{array}$ \\
\hline Brandt \& Dörfelt & 38 & $?$ & $\begin{array}{l}\text { LV } \\
\text { RV }\end{array}$ & $\mathrm{mg} / \mathrm{kg} \mathrm{d.w.}$ & $\begin{aligned} 1023 & \pm 98^{*} \\
927 & \pm 124\end{aligned}$ & $\begin{array}{l}150 \\
150\end{array}$ \\
\hline Chipperfield \& Chipperfield & 39 & $?$ & LV & mg/kg w. w. & $186 \pm 25$ & 25 \\
\hline Johnson et al. & 40 & $?$ & LV & $\mathrm{mg} / \mathrm{kg}$ w.w. & $221.3 \pm 16.8$ & 7 \\
\hline Elwood et al. & 41 & hard and soft & LV & $\mathrm{mg} / \mathrm{kg}$ w.w. & $177 \pm 32$ & 611 \\
\hline Speich et al. & 42 & $?$ & $\begin{array}{l}\text { LV } \\
\text { RV }\end{array}$ & $\mathrm{mg} / \mathrm{kg}$ protein & $\begin{array}{l}1315 \pm 165 \\
1883 . \pm 189\end{array}$ & $\begin{array}{l}26 \\
26\end{array}$ \\
\hline
\end{tabular}

Tab. 2. Change of postmortal electrolyte concentration in human heart after ischaemic heart death. Samples were taken from nonischaemic areas.

$$
\begin{aligned}
& \text { Abbreviations: w.w. = wet weight } \quad \text { NHD }=\text { non heart death } \\
& \text { d.w. = dry weight I IHD }=\text { ischaemic heart death } \\
& \text { n.d. = not determined AT = acute trauma } \\
& \text { SIHD = sudden ischaemic heart death } \quad \text { LV }=\text { left ventricle } \\
& \text { SNIHD = sudden non ischaemic heart death } \quad \text { RV = right ventricle } \\
& \text { (myocardial degeneration) } \quad A=\text { apex }
\end{aligned}
$$

\begin{tabular}{|c|c|c|c|c|c|c|c|c|c|c|}
\hline Author & Ref. & $\begin{array}{l}\text { Condition } \\
\text { examined }\end{array}$ & $\begin{array}{l}\text { Control } \\
\text { group }\end{array}$ & $\begin{array}{l}\text { Sample nu } \\
\text { Controls }\end{array}$ & $\begin{array}{l}\text { Number } \\
\text { examined }\end{array}$ & $\begin{array}{l}\text { Reference } \\
\text { point }\end{array}$ & $\begin{array}{l}\text { Locali- } \\
\text { sation }\end{array}$ & $\mathrm{Mg}^{2+}$ & $\mathrm{K}^{+}$ & $\mathrm{Ca}^{2+}$ \\
\hline Iseri et. al. & 3 & SIHD & NIHD & 16 & 3 & d.w. & LV & $-32.6 \%$ & $-2.9 \%$ & n.d. \\
\hline Behr \& Burton & 34 & SIHD & NIHD & 74 & 18 & w.w. & LV & $-11.6 \%$ & n.d. & n. d. \\
\hline $\begin{array}{l}\text { Chipperfield \& } \\
\text { Chipperfield }\end{array}$ & 35 & $\begin{array}{l}\text { SIHD } \\
\text { and SNIHD }\end{array}$ & NIHD & 14 & 19 & w.w. & LV & $-16.1 \%$ & $-6.9 \%$ & n.d. \\
\hline Anderson et al. & 36 & SIHD & AT & 54 & 27 & w.w. & A & $-24.1 \%$ & n.d. & $+26.9 \%$ \\
\hline $\begin{array}{l}\text { Chipperfield \& } \\
\text { Chipperfield }\end{array}$ & 39 & $\begin{array}{l}\text { SIHD } \\
\text { and SNIHD }\end{array}$ & NIHD & 158 & 59 & w.w. & LV & $-17.2 \%$ & $-24.0 \%$ & $+46.2 \%$ \\
\hline Johnnson et al. & 40 & SIHD & AT & 7 & 14 & w.w. & LV & $-12.2 \%$ & $-14: 9 \%$ & n.d. \\
\hline Elwood et al. & 41 & IHD & NIHD & 305 & 489 & w.w. & LV. & $-12.2 \%$ & n. d. & $+8 \%$ \\
\hline Speich et al. & 42 & SIHD & $\mathrm{AT}$ & 26 & 24 & protein & $\begin{array}{l}\text { LV } \\
\text { RV }\end{array}$ & $\begin{array}{l}-20.0 \% \\
-27.7 \%\end{array}$ & $\begin{array}{l}-9.1 \% \\
-25.5 \%\end{array}$ & $\begin{array}{l}+1.7 \% \\
+19.0 \%\end{array}$ \\
\hline
\end{tabular}


"cardiospecific", since, at least in skeletal muscle or diaphragm of the same cases, there was no change in the $\mathrm{Mg}^{2+}$ content $(32,34,36)$.

Some of these results suffer from methodological shortcomings. These are as follows:

1) Most of the authors related their analyses to wet weight instead of dry weight, despite the fact that it is known from animal infarction experiments that the water content of the heart is increased by $7.5 \%$ as a result of an interstitial oedema (51). Thus, in cases with oedema the relative loss found with wet weight as the reference point may overestimate the true change in cellular $\mathrm{Mg}^{2+}$.

2) Some authors did not specify exactly the region of the heart from which specimens were taken. Others gave no localization at all, or indicated only apex or ventricles as origin. It is known that, in man, the left and right ventricle have different $\mathrm{Mg}^{2+}$ concentrations $(33,38,42)$. Also in the dog the atria and various parts of the ventricles have different $\mathrm{Mg}^{2+}$ concentrations $(50,52,53)$. In dogs after injection of ${ }^{28} \mathrm{Mg}^{2+}$, the left ventricle exhibited a higher activity than the right one, and the highest intracardiac activity was found in the septum (54). According to Page \& Polimeni (55), in the rat heart, total $\mathrm{Mg}^{2+}$ is exchanged almost completely with one uniform rate constant so that one can conclude that a higher radioactivity corresponds to a higher $\mathrm{Mg}^{2+}$ content. Unfortunately, the difference of $\mathrm{Mg}^{2+}$ content in the various regions of the heart is in the same range as the amount of $\mathrm{Mg}^{2+}$ lost after myocardial infarction. Thus, for the sake of comparison, samples should be taken from the same region.
3) Tissue samples from noninfarcted regions have been analysed for $\mathrm{Mg}^{2+}$ without histological examination of an aliquot. However, even as a result of prior subclinical ischaemic episodes, there may be multiple small scars within the tissue which cannot be seen by gross inspection. Since connective tissue has a lower $\mathrm{Mg}^{2+}$ content than cardiac muscle, part of the described $\mathrm{Mg}^{2+}$ loss after infarction might be due to "dilution by collagen fibres" (24).

Although one could wish for a more exact determination of the decrease of $\mathrm{Mg}^{2+}$, it is confirmed that myocardial infarction results in lowered $\mathrm{Mg}^{2+}$ content of noninfarcted regions. It is not known whether we are dealing with a loss of $\mathrm{Mg}^{2+}$ preceeding the infarction and/or with $\mathrm{Mg}^{2+}$ loss as a consequence of the various hormonal and metabolic reactions that occur during myocardial infarction.

When myocardial $\mathrm{Mg}^{2+}$ is already lowered before infarction it would indicate a $\mathrm{Mg}^{2+}$ deficiency, which is perhaps exaggerated by soft water and/or a low $\mathrm{Mg}^{2+}$ intake. It is known that in rats with chronic $\mathrm{Mg}^{2+}$ deficiency, heart as well as muscle $\mathrm{Mg}^{2+}$ is decreased in the presence of hypomagnesaemia. Also, tissue $\mathrm{K}^{+}$is lowered while that of $\mathrm{Ca}^{2+}$ and $\mathrm{Na}^{+}$are increased (56-61). As can be seen in table 3 in $\mathrm{Mg}^{2+}$ deficiency the relative loss of cardiac $\mathrm{Mg}^{2+}$ varies between $2 \%$ and $20 \%$. Since some of the reported $\mathrm{Mg}^{2+}$ changes are at borderline significance one should not be surprised that the relative loss of $\mathrm{Mg}^{2+}$ from heart and skeletal muscle differed somewhat with the various authors. While some found a preferential $(56,59)$ or almost equivalent loss of $\mathrm{Mg}^{2+}$ from heart and skeletal muscle $(57,58)$, others have reported a preferential loss of $\mathrm{Mg}^{2+}$ from skele-

Tab. 3. Loss of $\mathrm{Mg}^{2+}$ from various organs of the $\mathrm{Mg}^{2+}$-deficient rat in percent of controls. The reduction of skeletal muscle $\mathrm{Mg}^{2+}$ content seems to be more pronounced at the lowest serum $\mathrm{Mg}^{2+}$ concentrations.

Abbreviations: w.w. = wet weight, d.w. = dry weight, * calculated from fig. 11 of l.c. (59).

\begin{tabular}{|c|c|c|c|c|c|c|c|c|c|}
\hline $\begin{array}{c}\text { Aunthor } \\
\text {. }\end{array}$ & Ref. & Species & $\begin{array}{l}\text { Weight } \\
\text { (g) }\end{array}$ & $\begin{array}{l}\mathrm{Mg}^{2+} \text { content } \\
\text { - of food }(\mathrm{mg} / \mathrm{kg}) \\
\text { (deficient) }\end{array}$ & $\begin{array}{l}\text { Period } \\
\text { (d) }\end{array}$ & $\begin{array}{l}\text { Reference } \\
\text { point }\end{array}$ & $\begin{array}{l}\text { Decrease } \\
(\%) \\
\text { Serum }\end{array}$ & Heart & Muscle \\
\hline Watchorn \& Mc Cance & 56 & Piebald & $55-83$ & 40 & 90 & w.w. & -52.8 & -7.4 & -3.9 \\
\hline Martindale \& Heaton & 57 & $\begin{array}{l}\text { Spprague } \\
\text { Dawley }\end{array}$ & 200 & 3 & 62 & $\begin{array}{l}\text { non- } \\
\text { collagen } \mathrm{N}\end{array}$ & -53.3 & -8.7 & -4.8 \\
\hline Günther & 58 & Wistar & 114 & 12 & 38 & d.w. & -74.5 & -15.7 & -12.9 \\
\hline Hunt & 59 & Wistar & $100-380$ & $2.5,5,10$ & $60-120$ & w.w. & $-40^{*}$ & $-20 *$ & 0 \\
\hline George \& Heaton & 60 & Wistar & 100 & 1 & 20 & w. w. & -69.1 & -3.9 & -28.4 \\
\hline Heroux et al. & 61 & $\begin{array}{l}\text { Sprague } \\
\text { Dawley }\end{array}$ & $85-100$ & 100 & 240 & w.w. & n.d. & -2.0 & -7.0 \\
\hline
\end{tabular}


tal muscle (60). It should be noted that in $\mathrm{Mg}^{2+}$ deficiency no significant loss of skeletal $\mathrm{Mg}^{2+}$ was observed in adult rats (62).

Apart from experimental variability, e.g. in ashing the samples, variations in results are perhaps caused by the interplay of factors such as different rates of physical activity and stress from noise, temperature and social factors etc. plus the different age and growth rate of the animals as well as duration of $\mathrm{Mg}^{2+}$ deficiency. Thus one can state that during $\mathrm{Mg}^{2+}$ deficiency, at least in young rats, $\mathrm{Mg}^{2+}$ loss is not cardiospecific. In man, $\mathrm{Mg}^{2+}$ deficiency was found with $(-11 \%)$ and without a decrease of skeletal muscle $\mathrm{Mg}^{2+}$ (63) but no data on cardiac $\mathrm{Mg}^{2+}$ content are available. In myocardial infarction, no loss of $\mathrm{Mg}^{2+}$ was found in skeletal muscle (see above). Furthermore, the relative decrease of $\mathrm{Mg}^{2+}$ in the noninfarcted areas was the same in hard and soft water regions (36). Therefore, at present more facts are needed to decide whether a cardiac lack of $\mathrm{Mg}^{2+}$ is a risk factor for myocardial infarction. However, when serum and muscle $\mathrm{Mg}^{2+}$ content are found to be normal in patients. with myocardial infarction, a preceeding $\mathrm{Mg}^{2+}$ deficiency can be excluded.

\section{Effect of Catecholamines on Cardiac $\mathbf{M g}^{2+}$ Content}

It is well established both in man and in animals that myocardial infarction is accompanied by increased catecholamine concentrations in blood and urine. The increase in catecholamine concentration is related to the severity of myocardial infarction and seems to precede the major complications of infarction (for review see l.c. (64)).

One of the various actions of catecholamines is to alter cardiac electrolyte metabolism by stimulation of $\alpha$ - as well as $\beta$-receptors. In experiments with rats and dogs injection of high doses of the $\beta$-agonist isoproterenol or of the $\alpha$-agonist phenylephrine and also of the $\alpha$-and $\beta$-active adrenalin produced a loss of cardiac $\mathrm{Mg}^{2+}$ in the range of $12-39 \%(23,65-68)$. The loss of $\mathrm{Mg}^{2+}$ was complete within $0.5-1$ hours (67) and was shown to be "cardiospecific" since in skeletal muscle, liver, erythrocytes and bone no effect could be observed $(23,67)$. The cardiac $\mathrm{Ca}^{2+}$ content showed a more pronounced increase of $2-3$ fold $(23,68,69)$ but the time course was different for loss of $\mathrm{Mg}^{2+}$ and gain of $\mathrm{Ca}^{2+}$, indicating that these two effects are not coupled, as already known from experiments on ${ }^{28} \mathrm{Mg}^{2+}$ transport (70). It should be noted that these changes in electrolyte content could be prevented by the specific $\alpha$ - or $\beta$ antagonists $(23,24,65)$.
Most interestingly a linear relationship between the increase of urinary catecholamine excretion and alterations of cardiac $\mathrm{Mg}^{2+}$ and $\mathrm{Ca}^{2+}$ could be established in rats that were $\mathrm{Mg}^{2+}$ deficient and noise stressed (31).

In animal experiments, injection of catecholamines also rapidly produced disseminated myocardial necroses $(23,24,65)$ and/or cardiac hypertrophy (for review see 1.c. (71)). Iñitial lesions were partly reversible. However, there was no quantitative correlation between the decrease in $\mathrm{Mg}^{2+}$ content and extent of necroses, although the effects on $\mathrm{Mg}^{2+}$ and $\mathrm{Ca}^{2+}$ content were additive (68).

It should be noted that the alterations in intracellular electrolyte concentrations always preceded the morphological changes $(23,65)$. When $\mathrm{MgCl}_{2}$ or $\mathrm{KCl}$ was given shortly before isoproterenol injection, the electrolyte changes as well as the morphological alterations could be prevented (69).

Somewhat different results were obtained when the effects of endogeneous and synthetic cạtecholamines were compared. After the injection of isoproterenol the extent of cardiac necroses was the same in normal and $\mathrm{Mg}^{2+}$ deficient rats (68). On the other hand, when endogeneous secretion of epinephrine and norepenephrine was increased by cold exposure (61, 72) or by heat or restraint (72) $\mathrm{Mg}^{2+}$ deficient rats responded with a higher incidence of myocardial necroses than normal rats. The stronger reaction in $\mathrm{Mg}^{2+}$ deficient rats was also found after injection of epinephrine (73). These results demonstrate that experiments with injected isoproterenol may not represent the endogeneous physiological stress reaction.

An understanding of the mechanism whereby catecholamines alter cardiac electrolyte content is beginning to evolve. In the case of $\mathrm{Mg}^{2+}$, both inhibited influx and accelerated efflux can be induced. In electrophysiological experiments, it has been shown that the rat heart may have a $\mathrm{Mg}^{2+}$-specific channel that is distinct from the $\mathrm{Ca}^{2+}$ channel. Isoproterenol was shown to inhibit $\mathrm{Mg}^{2+}$ influx through its channel (74). However, for criticism see l.c. (75). Further evidence for an effect of isoproterenol on $\mathrm{Mg}^{2+}$ uptake came from experiments with another model. In lymphoma cells, isoproterenol inhibited ${ }^{28} \mathrm{Mg}^{2+}$ inflụx but not that of ${ }^{45} \mathrm{Ca}^{2+}$, an effect that could be coun= teracted by propranolol. The isoproterenol-induced inhibition of ${ }^{28} \mathrm{Mg}^{2+}$ influx was mediated by the same receptors that activate adenylate cyclase. It remains to be ascertained whether the complete adenylate cyclase is necessary to close the $\mathrm{Mg}^{2+}$ channel, or whether this effect is produced by a protein coupled 
to a component of the enzyme system. Interestingly, cAMP and protein kinase were not involved in this mechanism (70). In the heart, a short time after injection of isoproterenol, the ATP and creatine phosphate content is considerably decreased $(69,71)$. In this process the concentration of free $\mathrm{Mg}^{2+}$ will increase and $\mathrm{Mg}^{2+}$ can thus be released from the heart muscle cell (see fig. 1 ).

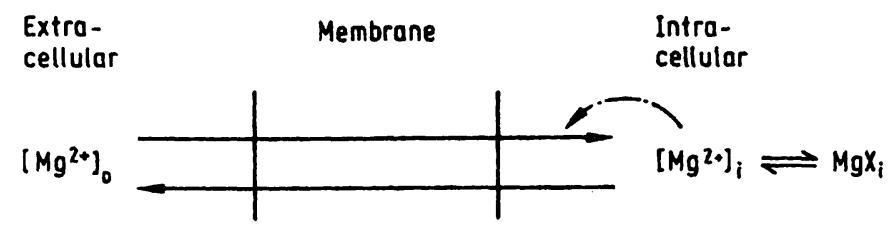

Fig. 1. Regulation of net $\mathrm{Mg}^{2+}$ fluxes. Feed-back inhibition of net $\mathrm{Mg}^{2+}$ influx at a physiological intracellular $\mathrm{Mg}^{2+}$ concentration $(-\cdot \rightarrow)$. Induction of net $\mathrm{Mg}^{2+}$ efflux when intracellular frce $\mathrm{Mg}^{2+}$ is increased by breakdown of ATP.

Abbreviations: $\left[\mathrm{Mg}^{2+}\right]_{0}=$ concentration of free extracellular $\mathrm{Mg}^{2+},\left[\mathrm{Mg}^{2+}\right]_{\mathrm{i}}=$ concentration of free intracellular $\mathrm{Mg}^{2+} . \mathrm{Mg} \dot{X}_{\mathbf{i}}=$ intracellular bound $\mathrm{Mg}^{2+}$

The isoproterenol-induced increase of cardiac $\mathrm{Ca}^{2+}$ content is brought about by binding of the catecholamine to the $\beta$-receptor, with subsequent activation of the adenylate cyclase. The increased cAMP activates a membrane-bound protein kinase that phosphorylates calciductin and thereby induces the specific increase of $\mathrm{Ca}^{2+}$ influx (76), either by chanelling or gating.

When we consider the pathophysiological relevance of a lowered content of cardiac $\mathrm{Mg}^{2+}$ it must be remembered that the biological effects of $\mathrm{Mg}^{2+}$ depend on its ability to form chelates, ATP being the most important intracellular ligand. Bound and free cellular $\mathrm{Mg}^{2+}$ form a $\mathrm{Mg}^{2+}$ buffer that maintains a constant concentration of free $\mathbf{M g}^{2+}$ (for review see l.c. (77)). On the basis of indirect evidence, it has been assumed that cardiac free $\mathbf{M g}^{2+}$ may be in the range of $1 \mathrm{mmol} / 1$ cell water (78). Recently, using ${ }^{31} \mathrm{P}$ nuclear magnetic resonance, a value of $2.5 \mathrm{mmol} / \mathrm{h}$ has been obtained for heart (79). With a $\mathrm{Mg}^{2+}$ sensitive microelectrode a free $\mathrm{Mg}^{2+}$-concentration of 3.1 $\mathrm{mmol} / \mathrm{l}$ has been determined in vèntricular muscle of the sheep and ferret (80). It is the total and not the free $\mathrm{Mg}^{2+}$ that has been measured until now in normal and diseased heart muscle of man. An $18 \%$ decrease of total $\mathrm{Mg}^{2+}$ as is seen after myocardial infarction in the noninfarcted areas is to small to reduce free cellular $\mathrm{Mg}^{2+}$ enough to affect metabolism, since the enzyme activity changes with $\mathrm{pMg}$. Indeed, it has been shown recently by means of ${ }^{31} \mathrm{P}$ nuclear magnetic resonance that, after ischaemic arrest of the heart for up to $35 \mathrm{~min}$, free $\mathrm{Mg}^{2+}$ remained constant at $2.5 \mathrm{mmol} / 1$ (79). Consequently, factors other than a change of free intracellular $\mathbf{M g}^{2+}$ are responsible for the severe alterations of cellular function after infarction. These could be the decrease in high energy phosphates and $\mathrm{pH}$ and the metabolic consequences of these events.

Furthermore, besides alterations of cytosolic $\mathrm{Na}^{+}$ and $\mathrm{K}^{+}$, the cytosolic $\mathrm{Ca}^{2+}$ concentrations may be increased and thereby involved in cardiac dysfunction. At present, this parameter has not been determined. The measured increase in total $\mathrm{Ca}^{2+}$ of the heart is due, in part, to an increase in the extracellular $\mathrm{Ca}^{2+}$ content. This is the result of enhanced extracellular fluid volume which has not yet been determined under these conditions. Furthermore, accumulation of $\mathrm{Ca}^{2+}$ by necrotic cells, together with their eventual calcification must be considered. Also, intracellular $\mathrm{Ca}^{2+}$ accumulation by living cells is enhanced, and the distribution of $\mathrm{Ca}^{2+}$ in these cells may be changed, e.g. an increased intracellular accumulation in mitochrondria and particularly in sarcoplasmic reticulum may occur.

In summary, animal experiments show that catecholamines induce a loss of cardiac $\mathrm{Mg}^{2+}$ and a gain of $\mathrm{Ca}^{2+}$. The alterations were more pronounced in cases of $\mathrm{Mg}^{2+}$ deficiency.

\section{Regulation of Myocardial $\mathbf{M g}^{2+}$ Content}

The above mentioned alterations in myocardial $\mathrm{Mg}^{2+}$ content as observed after myocardial infarction, or produced by high levels of either endogenous or synthetic catecholamines may be explained by the following regulatory mechanism (see fig. 1).

Intracellular free $\mathrm{Mg}^{2+}$ is in equilibrium with bound $\mathrm{Mg}^{2+}\left(\mathrm{MgX}_{\mathrm{i}}\right)$, which accounts for up to $90 \%$ of total intracellular $\mathrm{Mg}^{2+}$. Thus intracellular $\mathrm{Mg}^{2+}$ is buffered in the range of $\mathrm{pMg} 3$ so that $\mathrm{Mg}^{2+}$ dependent enzyme activation is optimal or nearly optimal (for review see 1.c. (77)). Intracellular free $\mathbf{M g}^{2+}$ concentration may also be held constant by feedback inhibition of net $\mathrm{Mg}^{2+}$ influx. Therefore total intracellular $\mathrm{Mg}^{2+}$ cannot be elevated above the physiological value when the extracellular concentration of free $\mathrm{Mg}^{2+}$ is increased.

However, total intracellular $\mathrm{Mg}^{2+}$ can be altered by a change in the concentration of $\mathrm{Mg}^{2+}$ binding ligands, i.e. when the ATP concentration in ascites tumour cells is enhanced by incubation with adenosine, and more $\mathrm{Mg}^{2+}$ is bound to ATP (81), or when lipolysis in fat cells is increased and water insoluble $\mathrm{Mg}^{2+}$ soaps are formed (see below), thereby causing a 
transient reduction in the concentration of intracellular free $\mathrm{Mg}^{2+}$. Under these conditions, a net uptake of $\mathrm{Mg}^{2+}$ takes place until the intracellular free $\mathrm{Mg}^{2+}$ reaches its original value. Thus total cellular $\mathrm{Mg}^{2+}$ increases.

On the other hand, there is no net efflux of $\mathrm{Mg}^{2+}$ from the cell when extracellular $\mathrm{Mg}^{2+}$ is omitted or complexed, indicating that there is no single steady state equilibrium of net $\mathrm{Mg}^{2+}$ influx and $\mathrm{Mg}^{2+}$ efflux. A net efflux $\mathrm{Mg}^{2+}$, with a consequent reduction of total cadiac $\mathrm{Mg}^{2+}$, occurs only when the intracellular concentration of free $\mathrm{Mg}^{2+}$ is transiently increased by breakdown of ATP; this is observed after injection of isoproterenol, during ischaemia or after myocardial infarction. As a consequence the intracellular free $\mathrm{Mg}^{2+}$ concentration remains constant (79).

\section{Serum $\mathrm{Mg}^{2+}$ after Myocardial Infarction}

When $\mathrm{Mg}^{2+}$ or other intracellular substances are lost from the ischaemic heart muscle they should reach the circulation. In fact, in dogs with coronary artery ligation the concentrations of $\mathrm{Mg}^{2+}$ and $\mathrm{K}^{+}$in plasma of the coronary sinus were found to rise by $24 \%$ and $12 \%$ respectively $8-11$ hours after ligation (46). However, when the experiment was repeated and $\mathrm{Mg}^{2+}$ was measured in peripheral serum, no increase but rather a decrease was detected after 1-4 hours, and this was normalized after 12-24 hours $(47,82)$.

Determination of serum $\mathrm{Mg}^{2+}$ in patients with myocardial infarction has yielded no uniform results (tab.4). Some authors did not detect any change in

Tab. 4. Change of serum $\mathrm{Mg}^{2+}$ after myocardial infarction. $\mathrm{n}=$ number examined

\begin{tabular}{|c|c|c|c|c|}
\hline Author & Ref. & $\mathbf{n}$ & $\begin{array}{l}\text { Time of } \\
\text { determination } \\
\text { after acute } \\
\text { myocardial } \\
\text { infarction }\end{array}$ & $\begin{array}{l}\text { Change } \\
(\%)\end{array}$ \\
\hline Brown et al. & 83 & 39 & ? & 0 \\
\hline Hughes \& Tonk & 84 & 40 & on admission & $-11.5 \%$ \\
\hline Hyatt et al. & 85 & 47 & $?$ & 0 \\
\hline Nath et al. & 82 & 20 & first week & $-26.1 \%$ \\
\hline Abraham et al. & 86 & 42 & $?$ & $-11.0 \%$ \\
\hline Lund et al. & 87 & 12 & within $4 \mathrm{~h}$ & 0 \\
\hline Petersen et al. & 88 & 40 & $?$ & $-3.8 \%$ \\
\hline Gould et al. & 89 & 34 & within $24 \mathrm{~h}$ & 0 \\
\hline Speich et al. & 90 & 49 & on the first day & 0 \\
\hline Dyckner & 91 & 342 & on admission & -4.7 \\
\hline Zumkley et al. & 92 & 17 & $?$ & $-12.8 \%$ \\
\hline Flinket al. & 93 & 16 & on admission & $-6.2 \%$ \\
\hline Rector et al. & 94 & 18 & within $24 \mathrm{~h}$ & $-11.2 \%$ \\
\hline
\end{tabular}

the concentration of serum $\mathrm{Mg}^{2+}(83,85,87,89$, 90 ), and some found on the $12^{\text {th }}$ day (90) a transient increase which is almost certainly not related to the changes observed during the first hours after infarction. Nevertheless most of the authors found a decrease of serum $\mathrm{Mg}^{2+}$ several hours after the onset of myocardial infarction. When we disregard a study with values obtained in the first and second week after myocardial infarction (82) then 7 groups with a total of 516 cases of myocardial infarction reported a decrease of serum $\mathrm{Mg}^{2+}$ by 3.8 to $12.8 \%$ with a mean value of approximately $9 \%$. In a quite recent investigation the patients were divided into two groups: one group with uncomplicated infarction and another group with complicated infarction, e.g. with severe ventricular ectopic beats, ventricular tachycardia, arrhythimia, and ventricular fibrillation. Lowered serum $\mathrm{Mg}^{2+}$ values were only found in the group with complicated myocardial infarction (91, 94). In other words: if, at the time of admission for myocardial infarction, serum $\mathrm{Mg}^{2+}$ is lowered, then a more severe development with cardiac arrhythmias must be expected. Within 2-3 days the lowered $\mathrm{Mg}^{2+}$ values return to a normal level (93).

The contradictory results, ranging from no change versus decrease of serum $\mathrm{Mg}^{2+}$ might be explained by a difference in clinical protocols. The time lag between onset of myocardial infarction and determination of $\mathrm{Mg}^{2+}$ varies between "admission" to the hos= pital and the second week after infarction. Furthermore the relationship between time of blood sampling and treatment of the patient is not recorded. After myocardial infarction, serum $\mathrm{Mg}^{2+}$ should be measured as early as possible and continued at short time intervals for the first day. This might elucidate the course of post-infarct changes in serum $\mathrm{Mg}^{2+}$.

What explanation can be offered to explain the change in serum concentration after myocardial in farction? In a first phase the $\mathrm{Mg}^{2+}$ released from infarcted and noninfarcted areas of the heart should lead to a transient increase in serum $\mathbf{M g}^{2+}$ concentration. However, the amount of released $\mathrm{Mg}^{2+}$ is small, the egress takes some time and some $\mathrm{Mg}^{2+}$ may be lost by urinary excretion during this time. Considering all these factors and calculating the distribution of $\mathrm{Mg}^{2+}$ over the extracellular fluid, a significant increase in serum $\mathrm{Mg}^{2+}$ is not bound to occur, but it may do so. Moreover the individual preinfarction serum $\mathrm{Mg}^{2+}$ concentration is usually unknown.

In a later phase most authors observed a decrease of serum $\mathrm{Mg}^{2+}$ concentration. One possible explanation is an increased renal loss of the cation following 
the increased secretion of catecholamines, probably through an indirect effect in which catecholamine suppression of insulin secretion (for review see 1.c. (64)) raises blood glucose. In the rat it has been shown that nonglycosuric hyperglycaemia, produced by an infusion of glucose, enhances urinary $\mathrm{Mg}^{2+}$ excretion (95). In man, ingestion or infusion of glucose likewise has been found to increase renal excretion of $\mathrm{Mg}^{2+}(96,97)$. In parallel to this in diabetic patients the urinary $\mathrm{Mg}^{2+}$ excretion rate was found to rise with increasing fasting blood glucose and glucosuria, leading to hypomagnesaemia (98). In rats with experimental myocardial infarction both hypermagnesaemia and increase in urinary excretion of $\mathrm{Mg}^{2+}$ have been detected (24). However, in man with myocardial infarction we know of no systematic investigation on renal $\mathrm{Mg}^{2+}$ excretion. In the only study we are aware of, urinary excretion of $\mathbf{M g}^{2+}$ showed a tendency to decrease after infarction (94). However, the authors collected urine over a period of 24 hours. Within this timespan serum $\mathrm{Mg}^{2+}$ has been known to increase towards normal levels (93). To ascertain that there is really no change in renal $\mathrm{Mg}^{2+}$ excretion, information on urinary $\mathrm{Mg}^{2+}$ and on glomerular filtration rate during the early post-infarct period is urgently needed when serum $\mathrm{Mg}^{2+}$ might be in a state of transient decrease.

There may be a further explanation for the post-infarct decrease in serum $\mathbf{M g}^{2+}$ concentration. Flink et al. (93) correlated the decrease of serum $\mathrm{Mg}^{2+}$ with a concomitant increase of free fatty acids. The rise in free fatty acid concentration is explained by an increased lipolysis which is induced by the enlarged catecholamine secretion involved in infarction. The same observation, a low $\mathrm{Mg}^{2+}$ concentration at increased free fatty acid concentration in serum was also found at ethanol withdrawal in dogs (99) and after infusion of adrenalin in ewes (100). Since the free fatty acids are able to bind $\mathrm{Mg}^{2+}$ it has been assumed that serum $\mathrm{Mg}^{2+}$ is thereby lowered (93). This must be doubted. Atomic absorption spectrometry, used by the authors, analyses both free and bound $\mathrm{Mg}^{2+}$; it does not detect changes in the ratio of free to bound $\mathrm{Mg}^{2+}$.

Perhaps a more reasonable explanation for lowering of total serum $\mathrm{Mg}^{2+}$ during increased lipolysis is an increased binding of $\mathrm{Mg}^{2+}$ by free fatty acids within the adipocytes. In vitro experiments with adipocytes support this view. Intact adipocytes showed an increased $\mathrm{Mg}^{2+}$ uptake after treatment with adrenalin (101). This suggests increased intracellular binding of $\mathrm{Mg}^{2+}$. The intracellular uptake of $\mathrm{Mg}^{2+}$ is a $\beta$-adrenergic effect and it is coupled to lipolysis (102). It must be realized that a small increase in $\mathrm{Mg}^{2+}$ uptake by the adipose tissue is sufficient to produce the small decrease $(-8 \%)$ in serum $\mathrm{Mg}^{2+}$ concentration.

These observations suggest the formulation of the following hypothesis. Increased catecholamine resulting from myocardial infarction causes loss of $\mathrm{Mg}^{2+}$ from the myocardium. Lipolysis is increased leading to an increase of free fatty acids, not only in serum, but also in adipose tissue. Therefore uptake and binding of $\mathrm{Mg}^{2+}$ by adipose tissue is increased. Due to different amounts of adipose tissue among individuals the decrease of serum $\mathrm{Mg}^{2+}$ might be different from patient to patient. The ratio of adrenalin: noradrenalin released in infarction might be different from patient to patient. In isolated subcutaneous adipocytes the relative potencies of catecholamines with $\beta$-adrenergic activity were: isoproterenol $>$ adrenalin $>$ noradrenalin $(103,104)$. Therefore, the decrease of serum $\mathrm{Mg}^{2+}$ may be more pronounced at a high ratio of adrenalin: noradrenalin. Furthermore in human adipocytes $\alpha$-agonists inhibit lipolysis (105-107) and there are different amounts of $\alpha$ - and $\beta$-receptors in adipose tissue from different areas of the body. Thus adipose tissue from some areas can be insensitive to the lipolytic effect of catecholamines (108). Moreover the lipolytic effect of noradrenalin in human tissue increased with the diameter of fat cells, with either obesity or fasting (109). Also, a variable antilipolytic effect of insulin must be considered, since suppression of insulin secretion in myocardial infarction (64) will vary with the amounts of catecholamines released. Interaction of these factors may explain why in some patients with myocardial infarction serum $\mathrm{Mg}^{2+}$ was found to decrease while it was unchanged in others.

That these mechanisms may really operate in vivo may be inferred from experiments with rats. In this species the relative potencies were isoproterenol: noradrenalin : adrenalin $=10: 2: 1$ (110). In contrast to the observations obtained in ewes administration of catecholamines in rats caused an increase of serum $\mathrm{Mg}^{2+}$ (111). Interestingly, in rats, the increase of serum $\mathrm{Mg}^{2+}$ concentrations was 5 times higher by s. c. injection of phenylephrine than by isoproterenol, although both substances caused the same release of $\mathrm{Mg}^{2+}$ from the heart (68), because isoproterenol produced lipolysis and $\mathrm{Mg}^{2+}$ uptake into adipose tissue.

In summary, we explain the decrease of peripheral serum $\mathrm{Mg}^{2+}$ observed after myocardial infarction by increased uptake and binding of the cation by adipose tissue as a consequence of increased lipolysis. In addition increased urinary excretion may be involved in the postinfarct decrease in serum $\mathrm{Mg}^{2+}$, 
provided that the glomerular filtration rate is not reduced beyond a critical level.

\section{Cardiomyopathy}

Human cardiomyopathy or myocardiopathy is a term often used for a rather heterogeneous group of heart diseases that are not secondary to coronary heart disease, rheumatic or congenital malformation of the heart and vessels, or arterial or pulmonary hypertension. As regards terminology and classification the literature is still rather equivocal (112114). Although there are differences in morphology regarding various forms of this disease the following alterations may be observed: cardiomegaly, endocardial thickening, a mural endocardial thrombus, myocardial scars without gross alterations in the coronary vessels. Light and electron microscopic examination reveals increased number of mitochrondria of variable size that are swollen and show ruptured cristae. The myofibrils are hypertrophic, often partially fragmented and in disarray. The T-tubules of the sarcoplasmic reticulum are swollen. Increased numbers of degenerative organelles, lysosomes, autophagic vacuoles and lipofuscin pigment granules are present.

The aetiology and pathogenesis of the so-called primary or idiopathic cardiomyopathy are unknown. The secondary cardiomyopathies include infectious myocarditis (viral, bacterial and others), metabolic cardiomyopathies (e.g. as a consequence of thyroid dysfunction), glycogen storage and nutritional deficiencies of vitamins and proteins, toxic cardiomyopathies and several other forms. $\mathrm{Mg}^{2+}$ deficiency may be involved in some of these conditions, e.g. in alcoholism $(115)$, in hyperthyreosis $(116,117)$ and in protein malnutrition (118). However, as yet, there is no proof that $\mathrm{Mg}^{2+}$ deficiency is really involved in the pathogenesis of some of these cardiomyopathies.

An experimental model for this disease is the hereditary spontaneous cardiomyopathy in inbred hamster strains. These hamsters develop myocardial degeneration and myolysis similar to human cardiomyopathy between the 30th and 40th day of life. Their hearts exhibit a decreased content of $\mathrm{Mg}^{2+}$ and an increased content of $\mathrm{Ca}^{2+}$ before the lesions develop. The decreased myocardial $\mathrm{Mg}^{2+}$ content does not persist, but the $\mathrm{Ca}^{2+}$ content rises markedly between the 60th and 80th day. The change in $\mathrm{Na}^{+}$and $\mathrm{K}^{+}$ content is small and not significant (119). Hamsters, when 30 days old and in the prenecrotic stage are more sensitive to isoproterenol-induced $\mathrm{Ca}^{2+}$-uptake (120) and necrosis (121) than normal animals. $\mathrm{Ca}^{2+}$ accumulation and myocardial necrosis during both the prenecrotic and the cardiomyopathic stage, could be prevented by the $\mathrm{Ca}^{2+}$ antagonist verapamil $(120,121)$. Also, high doses of $\mathbf{M g}^{2+}$ had a prophylactic effect against cellular $\mathrm{Ca}^{2+}$ accumulation and on the development of necrosis, probably by $\mathrm{a} \mathrm{Ca}^{2+}$ antagonistic effect (122). Although much remains to be established, the hamster cardiomyopathy probably is caused by a defect in sarcolemmal $\mathrm{Ca}^{2+}$ transport; this in turn leads to increased $\mathrm{Ca}^{2+}$ uptake and damage of heart mitochondria and consequently to a deficient energy supply to the cell with ensuing necrosis (123).

Subjective and objective improvement (124) during chronic verapamil therapy suggests that a mechanism similar to that in the animal may be involved in human cardiomyopathy. Also of significance is the increased membrane permeability and cytosolic $\mathrm{Ca}^{2+}$ concentration caused by viral infection (125). Perhaps the same mechanism is operative in human viral cardiomyopathy. It is possible that in all cases of myocardial cell damage, an increäse in intracellular $\mathrm{Ca}^{2+}$ may be responsible. This tentative conclusion agrees with the hypothesis that in general cell death as induced by ischaemia, viruses, radiation, drugs and toxins is mediated by an increased irreversible cellular $\mathrm{Ca}^{2+}$ accumulation and an elevated cellular $\mathrm{Ca}^{2+}$ concentration (126).

\section{Coronary Artery Spasm}

It is now generally accepted that spontaneous rest angina (Prinzmetal's variant anigina) is caused by a transient coronary artery "vasospasm". Recently it has been suggested that coronary "vasọspasm." might also be involved in a variety of other cardiac diseases such as the more common exertionial type of angina pectoris, myocardial infarction and sud= den-death coronaries. The mechanism of coronary "vasospasm" appears to be a multifactorial event which remains to be elaborated. The effect of vasoactive hormones depends on the kind and number of agonistic and antagonistic reacting receptors in distinct parts of the coronary arteries. Activation of adrenergic but also of muscarinergic, serotoninèrgic and histaminergic receptors might be involved. Moreover, prostaglandins and related substances such as thromboxane $A_{2}$ might cause coronary spasm. $\mathrm{Ca}^{2+}$ antagonistic drugs have been used successfully to interrupt and prevent coronary "vasospasm" (for review see l.c. $(127-129))$. In this review we mainly focus on the role of $\mathrm{Mg}^{2+}$ as the physiological $\mathrm{Ca}^{2+}$ antagonist in the regulation of the coronary vasospasm. Not included is the function of $\mathrm{Mg}^{2+}$ in the development of acute coronary thrombosis or sclero- 
sis and the relationship of these disturbances to coronary vasospasm.

It is now well established that the contractile activity of vascular smooth muscle is regulated mainly by the myoplasmic free $\mathrm{Ca}^{2+}$ concentration. The $\mathrm{Ca}^{2+}$ control of the actomyosin system is the final common pathway by which neurotransmitters, hormones, drugs, and other ions all exert their influence on vascular smooth muscle. In vivo perfusion of arteries with a solution that selectively produced only a local hypermagnesaemia was followed by a decrease in resistance in the forelimb $(130,131)$, kidney $(130$, $132)$, coronary (133), gastric (134), mesenteric $(134,135)$ and hepatic $(136)$ vascular beds of anaesthetized dogs. In the dog, perfusion of the forelimb, the hind leg, the renal artery and the coronaries with low $\mathrm{Mg}^{2+}$ blood was without a measurable effect on the arterial pressure $(137,138)$. On the other hand in the same species intraveneous infusion of a salt solution that reduced extracellular $\mathrm{Mg}^{2+}$ concentration resulted in a significant increase of mean blood pressure (139). Also, in rats, perfusion of the ileocolic artery with $\mathrm{Mg}^{2+}$-free Ringer solution induced a reduction of ileocolic vein outflow and a reduction of arteriolar lumen size (140).

The mechanism of $\mathrm{Mg}^{2+}$ induced vasoconstriction and vasodilation has been investigated in detail with isolated blood vessels in vitro. Lowering the external $\mathrm{Mg}^{2+}$ concentration induces a rapid rise in tension development of isolated aortic strips of the rat while an elevation of $\mathrm{Mg}^{2+}$ results in lowering of the baseline tension $(141,142)$. Also, the effects of 0 and 4.8 $\mathrm{mmol} / 1 \mathrm{Mg}^{2+}$ on baseline tension of isolated coronary arteries of dogs have been documented. In the absence of $\mathrm{Mg}^{2+}$ tension is increased. The change of tension is rapid (143).

It seems to be more important that extracellular $\mathrm{Mg}^{2+}$ also modulates hormone and drug induced alterations in baseline tension. In isolated aortic strips of the rabbit removal of $\mathrm{Mg}^{2+}$ is followed by a $10-$ $30 \%$ increase of the contractive effect of acetylcholine, angiotensin II and $\mathrm{K}^{+}$. On the other hand the adrenalin-induced contraction was reduced in the absence of $\mathrm{Mg}^{2+}$ (read from fig. 1 and 2 of 1.c. (144)). Qualitatively the same effect, a depression of the contractile response elicited by supramaximal doses of adrenalin upon omission of $\mathrm{Mg}^{2+}$, was observed in rat aortic strips (145). Interestingly, a more pronounced effect was seen when the contractile action of various hormones was tested on different segments of isolated coronary arteries of the dog. Lowering the external $\mathrm{Mg}^{2+}$ from $1.2 \mathrm{mmol} / 1$ to zero resulted in an approximate $32-57 \%$ increase of ten- sion produced by angiotensin II. The analogous data were $81-100 \%$ for serotonin and $90-120 \%$ for the $\alpha$-effect of noradrenalin when assessed against propranolol (143). In another study on canine coronaries the effect of catecholamines was investigated in the presence of $1.2 \mathrm{mmol} / 1 \mathrm{Mg}^{2+}$. Here, adrenalin elicited weak contractions in large coronaries, but relaxation in small coronaries. However, noradrenalin produced relaxation in both large and small coronaries. Propranolol treatment enhanced the adrenalin induced contractile responses of large arteries and on small arteries it reversed relaxation into contraction. Furthermore, the noradrenalin-induced relaxation was changed into contraction after propranolol treatment (145). Finally it should be mentioned that on aortic strips of the rat, the lowering of $\mathrm{Mg}^{2+}$ from $1.2 \mathrm{mmol} / \mathrm{l}$ to zero attenuates the contractile response to $\mathrm{PGF}_{2 \alpha}$ approximately by $75 \%$ (read from fig. 5 of 1.c. (146)).

On the other hand, elevation of the extracellular $\mathrm{Mg}^{2+}$ concentration attenuates the contractions elicited by several neurohumoral agents and $\mathrm{K}^{+}$. Raising external $\mathrm{Mg}^{2+}$ above physiologic levels to $4 \mathrm{mmol} / 1$ depressed the tension measured in the presence of adrenalin, angiotensin, serotonin and $\mathrm{K}^{+}$ by approximately 34 to $69 \%$ in isolated rat aorta (calculated from tab. 1 of 1.c. (140)). Essentially the same effect was observed with isolated coronary arteries of the dog. The contractile tension that developed in response to angiotensin II, serotonin, noradrenalin (in the presence of propranolol) and $\mathrm{K}^{+}$was decreased by elevation of $\mathrm{Mg}^{2+}$ from 1.2 to $4.8 \mathrm{mmol} / \mathrm{l}$ (143). In contrast the contractile response of isolated rat aorta to $\mathrm{PGF}_{2 \alpha}$ was increased when $\mathrm{Mg}^{2+}$ was elevated to $5 \mathrm{mmol} / \mathrm{l}$ (146).

Obviously, the mechanism whereby external $\mathrm{Mg}^{2+}$ influences arterial smooth muscle tone is not a direct one. Experiments with isolated rat aortic strips have shown that the contraction induced by withdrawal of $\mathrm{Mg}^{2+}$ is potentiated by the addition of CaEDTA which exchanges some $\mathrm{Ca}^{2+}$ for $\mathrm{Mg}^{2+}$ and thus chelates and removes surface $\mathrm{Mg}^{2+}$ from the smooth muscle cells. On the other hand, EGTA which is known to chelate $\mathrm{Ca}^{2+}$ in preference to $\mathrm{Mg}^{2+}$ rapidly reverses the contraction induced by withdrawal of $\mathrm{Mg}^{2+}$ (147).

Furthermore, it has been demonstrated that in aortic strips of rabbit and rat the uptake of ${ }^{45} \mathrm{Ca}^{2+}$ is depressed by external $\mathrm{Mg}^{2+}$, but it increases when $\mathrm{Mg}^{2+}$ is withdrawn. That this $\mathrm{Mg}^{2+}$ dependent ${ }^{45} \mathrm{Ca}^{2+}$ uptake does not simply reflect extracellular binding, but is due to intracellular uptake, has been deduced from experiments with the lanthanum 
nique which removes the $\mathrm{Ca}^{2+}$ bound to the membrane surface. Furthermore, it has been shown that ${ }^{45} \mathrm{Ca}^{2+}$ efflux is delayed by an increase of external $\mathrm{Mg}^{2+}$. Based on these findings, it has been proposed that $\mathrm{Mg}^{2+}$ effects vascular smooth muscle tone by regulating $\mathrm{Ca}^{2+}$ permeability and exchange (148, 149).

Based on the aforementioned experimental evidence, it has been proposed that $\mathrm{Mg}^{2+}$ depletion might be one of the factors contributing to coronary vasospasm $(143,150)$. However, it should be remembered that the majority of experiments were performed in vitro on isolated aortic or other arterial strips maintained in blood-free Ringer solution and mounted under isometric tension. In order to obtain clear cut results $\mathrm{Mg}^{2+}$ concentrations have been tested far beyond the range of hypomagnesaemia usually observed in patients. For instance, after myocardial infarction, serum $\mathrm{Mg}^{2+}$ is reduced in the range of only $8 \%$ (see above); but, in the in vitro experiments, $\mathrm{Mg}^{2+}$ wàs lowered by $50-80 \%$ (e.g. l.c. (143)) or was withdrawn completely. Unfortunately, so far no dose-response curves have yet been published to show the effect of various $\mathrm{Mg}^{2+}$ concentrations on the tension of coronary arterial strips. Therefore, one cannot assess whether the small changes of serum $\mathrm{Mg}^{2+}$ occuring in patients have a measurable effect on resting tension in vitro. Furthermore, to our knowledge, only one in vivo experiment has shown that perfusion of an artery with $\mathrm{Mg}^{2+}$ free solution is followed by a narrowing of the lumen of the corresponding arteriole; however, this experiment was done in the rat by perfusing the ileocolic artery with a $\mathrm{Mg}^{2+}$ free Ringer solution (140) and not with blood selectively low in $\mathrm{Mg}^{2+}$. It must be remembered that perfusion of the coronary artery of the dog with blood selectively low on $\mathrm{Mg}^{2+}$ was without effect on coronary artery pressure (137). Finally it should be noted that these studies on coronary artery spasm were performed on healthy tissue but not on pathological or diseased tissue and that the animals used were anaesthetized. With these limitations in mind one can conclude that the $\mathrm{Mg}^{2+}$ deficiency coronary vasospasm hypothesis needs further clarification. Perhaps not $\mathrm{Mg}^{2+}$ deficiency per se but its effect on vasopressive hormones and/or cations such as $\mathrm{Ca}^{2+}$ and $\mathrm{Na}^{+}$may be involved in coronary vasospasm.

\section{Cardiac Arrhythmia and Electrocardiogram in $\mathbf{H y}$ - pomagnesaemia}

The effect of experimental $\mathrm{Mg}^{2+}$ deficiency on heart action has been studied primarily in rats and dogs. In the early phase of $\mathrm{Mg}^{2+}$ deficiency in young growing rats, a slight increase of heart rate was observed which was associated with a transient hyperaemia of the skin. Subsequently, when hyperaemia spontaneously disappeared, the increased heart rate fell concomitantly to a normal rate. Obviously, the transient tachycardia might be explained by arterial hypotension during the hyperaemic phase. In the later hyperexcitable phase of $\mathrm{Mg}^{2+}$ deficiency, the heart rate remained unchanged. It wàs only just before the onset of a convulsion that the heart rate was found to be markedly depressed, although it slowly returned to normal after recovery. However, during the bradycardia, a marked arrhythmia was present $(151,152)$. $\mathrm{Mg}^{2+}$ deficient rats without convulsions did not exhibit changes in the heart rate. $(153,154)$. Nevertheless, the $\mathrm{Mg}^{2+}$ deficient rats tend to have extrasystoles $(152,153)$. Additional electrocardiogram abnormalities in $\mathrm{Mg}^{2+}$ deficient rats are lengthened $\mathrm{P}-\mathrm{R}$ intervals and alterations of the $\mathrm{S}-\mathrm{T}$ segment (153). In anaesthetized, $\mathrm{Mg}^{2+}$ deficient rạtš, later investigators found only a highly significant decrease of the T-wave amplitude but no change of other amplitudes or segments (154). Unfortunately, all the above mentioned authors did not report whether the animals exhibited a selective hypomagnesaemia or were also hypokälaemic and/or hypocalcaemic.

In chronic $\mathrm{Mg}^{2+}$-deficient dogs, which usually show no skin hyperaemia, some authors noted no change of heart rate when compared to animals on control diets $(155,156)$ whereas others have noted the tendency for intermittent or continuous sinus tachycardia (158). The electrocardiogram of the chronic $\mathrm{Mg}^{2+}$ deficient dogs revealed a depression of the $R=S-T$ segment $(156,157)$ and widened QRS. Occasional= ly, ventricular premature beats and bigeminal rhythm were also observed (158). Furthermore, there was a frequent occurrence of $\mathrm{T}$-wave abnormalities. A peaking of the $\mathrm{T}$-wave $(157,158)$ as well as a flattened or inverted negative T-wave (155, 156) was reported. Since peaking of the $T$-wave is usually associated with hyperkalaemia it should be noted that $\mathrm{Mg}^{2+}$ deficient dogs were either normokalaemic (158) or hypokalaemic (157). The flattened or negative $\mathrm{T}$-wave which is usually seen in hypokalaemic but normomagnesaemic dogs (158) has also been found in chronic $\mathrm{Mg}^{2+}$ deficient dọgs that had normal serum $\mathrm{K}^{+}$values (156).

Interestingly, the profound changes seen in chronic $\mathrm{Mg}^{2+}$ deficient dogs were not seen in these animals during short termed haemodialysis which was designed to produce a selective acute $\mathrm{Mg}^{2+}$ depletion to approximately one half of its initial plasma value. Only a $15 \%$ increase of heart rate and a slight de- 
Tab. 5. Reported cases of arrhythmias with isolated hypomagnesaemia.

\begin{tabular}{|c|c|c|c|c|}
\hline Author & Ref. & Abnormality & $\mathrm{Mg}^{2+}$ in serum & Main disease \\
\hline Kellaway & 166 & $\begin{array}{l}\text { Abnormal T-wave flattening, } \\
\text { ST depression }\end{array}$ & $0.65 \mathrm{mmol} / 1$ & $\begin{array}{l}\text { Prolonged gastric suction and infusion } \\
\text { following sigmoid colectomy }\end{array}$ \\
\hline Gerst et al. & 167 & Sinus tachycardia & $0.19 \mathrm{mmol} / \mathrm{h}$ & Extensive small bowel resection \\
\hline Loeb & 168 & $\begin{array}{l}\text { Paroxysmal ventricular fibrillation } \\
\text { Paroxysmal ventricular fibrillation }\end{array}$ & $\begin{array}{l}0.25 \mathrm{mmol} / \\
0.50 \mathrm{mmol} /\end{array}$ & $\begin{array}{l}\text { Alcoholism } \\
\text { Rheumatic heart disease }\end{array}$ \\
\hline Ricketts & 169 & Alternating upright and inverted $T$-waves & $0.38 \mathrm{mmol} / \mathrm{\Lambda}$ & Alcoholism \\
\hline Chadda et al. & 170 & Supraventricular tachycardia & $0.16 \mathrm{mmol} / \mathrm{\Lambda}$ & Prolonged diarrhoea \\
\hline Iseri et al. & 3 & Atrial and ventricular arrhythmia & $0.61 \mathrm{mmol} / \AA$ & Alcoholism and digitalis intoxication \\
\hline Mc Mullen & 171 & Asystolic cardiac arrest & $0.30 \mathrm{mmol} / 1$ & Diabetic ketoacidosis \\
\hline Klauser & 172 & $\begin{array}{l}\text { Ventricular tachycardia with "reversal of } \\
\text { points", prolonged Q-T segment }\end{array}$ & $0.50 \mathrm{mmol} / \Lambda$ & Nothing known \\
\hline
\end{tabular}

crease in the $P-R$ and $Q-T$ intervals were observed (159). During prolonged dialysis of more than 3-6 hours, the electrocardiographic changes associated with hypomagnesaemia per se were $\mathrm{S}-\mathrm{T}$ segment depression and $T$-wave inversion (160). It should be mentioned that none of the authors found a definite correlation of the electrocardiographic changes with the extent of hypomagnesaemia. This is true for chronic $\mathrm{Mg}^{2+}$ deficiency, as well as for acute and selective $\mathbf{M g}^{2+}$ depletion by dialysis.

Chronic as well as acute $\mathrm{Mg}^{2+}$ deficient dogs show an increased sensitivity to cardiac glycosides, as characterized by a lowered threshold dose for toxic arrhythmia $(157,160,161)$ or by a prolonged duration of digitalis poisoning (162). By recourse to parenteral administration of $\mathrm{Mg}^{2+}$ in dogs made acutely $\mathrm{Mg}^{2+}$ deficient via haemodialysis, the cardiac glycoside-induced arrhythmia could be immediately reversed into sinus rhythm (160). Also, in normomagnesaemic dogs, cardiac glycoside-induced ventricular tachycardia could be converted into sinus rhythm by $\mathrm{Mg}^{2+}$ infusion $(163,164)$.

In contrast to rats and dogs the chronic $\mathrm{Mg}^{2+}$-deficient young cebus monkeys developed a bradycardia. The main and consistent electrographic change was an elevated $\mathrm{S}-\overrightarrow{\mathrm{T}}$ segment and a marked peaking of the T-wave. No arrhythmias were observed. As in rats and dogs the $\mathrm{Mg}^{2+}$-deficient monkeys showed a decreased tolerance to cardiac glycoside administration. The animals were hypomagnesaemic as well as hypokalaemic (165).

In humans, hypomagnesaemia ${ }^{1}$ ) may similarly produce cardiac arrhythmias. However, arrhythmias and electrocardiographic abnormalities associated solely with hypomagnesaemia are rare. The few cases in the literature we are aware of are listed in table 5. It should be added that no arrhythmias and only minor electrographic changes could be observed in normal humans subjected to an experimental dietary induced $\mathrm{Mg}^{2+}$ depletion, resulting in a hypomagnesaemia with values below $0.5 \mathrm{mmol} / \mathrm{l}$ (173).

All the other cases of hypomagnesaemia reported in the literature provide no further evidence for a $\mathrm{Mg}^{2+}$ specific cardiac effect. In some studies the concomitant values of other electrolytes have not been documented. In other papers hypomagnesaemia has been shown to be associated with hypokalaemia and/or changes of serum $\mathrm{Ca}^{2+}$. Usually this pattern was observed after myocardial infarction. In a study of 342 patients with myocardial infarction reported by Dyckner et al. (91), $46 \%$ were hypomagnesaemic. The incidence of ventricular ectopic beats, ventricular tachycardia, ventricular fibrillation, atrial fibrillation, and supraventricular tachycardia of the hypomagnesaemic cases was higher than in normomagnesaemic patients. It should be noted that in $3 \%$ of the patients hypermagnesaemia was detected, and the incidence of AV blocks and supraventricular bradycardia was higher in this group. Concerning distur-

1) Hypomagnesaemia is as yet not unambiguously defined. On average, the normal serum $\mathbf{M g}^{2+}$ concentration amounts to $0.89 \mathrm{mmol} / 1$. The lower limit $( \pm 2 \mathrm{SD}$ ) is $0.7 \mathrm{mmol} / 1$. Some people with serum $\mathrm{Mg}^{2+}$ concentrations below this limit may develop a tetanic syndrome, but others will not. Perhaps one explanation for the nonuniform response is that only free extracellular $\mathrm{Mg}^{2+}$ is biologically active. Because this value is difficult to determine, total serum $\mathrm{Mg}^{2+}$ is usually measured. Another factor is that in some subjects the consequence of hypomagnesaemia, e.g. increased membrane permeability, may be compensated by a well developed active membrane transport system. 
bances of other electrolytes, it has been noted that $10 \%$ of the patients were hypokalaemic but no analysis of arrhythmias for isolated hypomagnesaemia was presented.

In the same study it has been shown that, in approximately $9 \%$ of 563 patients admitted to the cardiac unit of the hospital with diagnosis other than myocardial infarction, serum $\mathrm{Mg}^{2+}$ was lower than 0.7 $\mathrm{mmol} / \mathrm{h}$; in this group, there was a higher incidence of supraventricular tachycardia (91).

Furthermore, an association between hypomagnesaemia and arrhythmias has been described in patients during open heart surgery using cardiopulmonary bypass. Some of the patients studied remained in persistent ventricular fibrillation despite standard medical therapy. However, successful defibrillation was finally achieved after intravenous $\mathrm{Mg}^{2+}$ administration (174). This initial finding was followed by several investigations on the importance of $\mathrm{Mg}^{2+}$ supplementation in 'open heart surgery or in cardioplegic solutions (for review see l.c. (175)).

In patients with various forms of arrhythmias due to digitalis poisoning, a high prevalence of hypomagnesaemia exists (176-180). However, there was no relationship between hypomagnesaemia and cardiac glycoside concentration in serum $(179,180)$ nor was there a relation between the type of arrhythmias and the serum $\mathrm{Mg}^{2+}$ level (176). In these investigations, $\mathrm{Mg}^{2+}$ was lowered by only $6-15 \%(178-180)$ and sometimes the decrease was so small that it was not statistically significant $(176,177,181)$.

An association between hypomagnesaemia and arrhythmias has also been found in alcoholics during alcohol withdrawal $(3,168,182)$. However, although it is known that hypomagnesaemia may occur during alcohol withdrawal $(183,184)$, only a limited number of cases have so far been reported with hypomagnesaemia at the time of arrhythmia, but one can anticipate that more will be detected in the future. Also before onset of delirium tremens during chronic alcoholism a hypomagnesaemia may be already present in up to $40 \%$ of the patients. Approximately $20 \%$ of the alcoholics showed a sinus tachycardia, but there are no reports on the prevalence of hypomagnesaemia in this group (185).

Other cases reported concern the malabsorption syndrome. Three patients with a hypomagnesaemia and hypocalcaemia showed S-T segment depression, slight prolongation of QT interval and low wave voltage (186). Another case with hypomagnesaemia, hypokalaemia and hypercalcaemia had a prolonged $\mathrm{Q}-\mathrm{T}$ segment (184).
During the course of exchange transfusion with citrated blood both a hypomagnesaemia and hypocalcaemia followed by cardiac arrhythmias and seizures may occur. At a serum $\mathrm{Mg}^{2+}$ concentration below $0.4 \mathrm{mmol} / \mathrm{h}$ a flattening of $\mathrm{T}$-waves was observed $(187-190)$. However, under this condition the concentrations of free $\mathrm{Mg}^{2+}$ and $\mathrm{Ca}^{2+}$ are, as yet, not accurately defined.

The correlation between hypomagnesaemia and cardiac arrhythmia is not necessarily specific. However, the beneficial effect of parenteral $\mathrm{Mg}^{2+}$ on various forms of arrhythmias either in man (191-193) or in animals (194) has been known for a long time. Unfortunately, these authors did not determine $\mathrm{Mg}^{2+}$ in serum before and after $\mathrm{Mg}^{2+}$ administration. In a quite recent study, it was reported that the frequency of ventricular ectopic beats in hypomagnesaemic patients could be reduced significantly by infusion of $\mathrm{Mg}^{2+}$. Although some of the patients were hypokalaemic the average $\mathrm{K}^{+}$serum value of the $\mathrm{Mg}^{2+}$ treated group was in the normal range (195). Interestingly, some of the above-mentioned cases with selective hypomagnesaemia were reported to be réfractory against the usual therapy, unless $\mathrm{Mg}^{2+}$ was given intravenously $(3,167,170,171)$.

The pathophysiological mechanism governing the effect of hypomagnesaemia on arrhythmias is not known in detail. In most cases of hypomagnesaemia other serum electrolytes are also changed. But even when there is really an isolated hypomagnesaemia, this also leads to a decrease in cellular $\mathrm{K}^{+}$of the heart, while $\mathrm{Ca}^{2+}$ is increased. This effect may be enhanced by the increased catecholamine secretion in hypomagnesaemia (31). The lowering of intracellular $\mathrm{K}^{+}$could lead to a less negative membrane potential, so that the cell would be more easily excited and arrhythmia could more readily occur. An argument for the primary role of $\mathrm{Mg}^{2+}$ is the observation that in cases of hypomagnesaemia with ventricular ectopic beats, the $\mathrm{K}^{+}$of skeletal muscle was found to be reduced and that infusion of $\mathrm{K}^{+}$did not result in any change in muscular $\mathrm{K}^{+}$content nor in the frequency of ventricular ectopic beats. A significant increase of muscular $\mathrm{K}^{+}$and a decrease of frequency of ventricular ectopic beats was observed only after infusion of $\mathrm{Mg}^{2+}$ (195).

\section{Conclusion}

$\mathrm{Mg}^{2+}$ deficiency with and without hypomagnesaemia per se may not cause myocardial infarction. However, it may facilitate catecholamine-stimulated loss of $\mathrm{Mg}^{2+}$, coronary vasospasm and neoroses. Lack of 
$\mathrm{Mg}^{2+}$ and excess of catecholamines act synergistically in the heart and the coronary arteries. Moreover, hypomagnesaemia in combination with myocardial infarction, digitalis poisoning, or alcohol withdrawal favours occurrence of arrhythmias. In hypomagnesaemia, secretion of catecholamines is increased, and catecholamines can perpetuate hypomagnesaemia by stimulation of urinary $\mathrm{Mg}^{2+}$ loss or increased li-

\section{References}

1. Lossnitzer, K. (1971) Klin. Wochenschr. 49, 1153-1163.

2. Seelig, M. S. \& Heggtveit, H. A. (1974) Am. J. Clin. Nutr. 27, 59-79.

3. Iseri, L. T., Freed, J. \& Bures, A. R. (1975) Am. J. Med. 58, 837-846.

4. Burch, G. E. \& Giles, T. D. (1977) Am. Heart J. 94, 649657.

5. Chipperfield, B. \& Chipperfield, J. R. (1977) Am. Heart J. 93, 679-682.

6. Shine, K. I. (1979) Am. J. Physiol. 237, H 413-423.

7. Krasner, B. S. (1979) Can. Anaesth. Soc. J. 26, 181-185.

8. Schroeder, H. A. (1960) J. Am. Med. Assoc. 172, 19021908.

9. Morris, J. N., Crawford, M. D. \& Heady, J. A. (1961) Lancet $J, 860-862$.

10. Schroeder, H. A. (1966) J. Am. Med. Assoc. 195, 81-85.

11. Crawford, T. \& Crawford, M. D. (1967) Lancet I, 229232.

12. Crawford, M.D., Gardner, M. J. \& Morris, J. N. (1968) Lancet $I, 827-831$

13. Anderson, T. W., Le Riche, W. H. \& MacKay, J. S. (1969) New Engl. J. Med. 280, 805-807.

14. Karppanen, H., Pennanen, R. \& Passinen, L. (1978) Adv. Cardiol. 25, 9-24.

15. Marier, J. R. (1978) Rev. Can. Biol. 37, 115-125.

16. Marier, J. (1981) Magnesium Bull. 3 (1a), 48-54.

17. Neri, L. C., Hewitt, D. \& Schreiber, G. B. (1974) Am. J. Epidemiol. 99, 75-88.

18. Neri, L. C., Mandel, J. S. \& Hewitt, D. (1972) Lancet $I$, 931-934.

19. Lowe, C. R., Robert, C. J. \& Lloyd, S. (1971) Brit. Med. J. 2, 357-361.

20. Masironi, R., Pisa, Z. \& Clayton, D. (1979) Bull. Wrld. Hith. Organ. 57, 291-299.

21. Mitchell, J. R. A. (1977) Lancet $I, 295-297$.

22. Heggtveit, H. A., Hermann, L. \& Mishra, R. K. (1964) Am. J. Pathol. 45, 757-782.

23. Lehr, D. (1969) Ann. N:Y. Acad. Sci. 156, 344-378.

24. Lehr, D., (1981) Magnesium Bull. 3 (1a), 178-191.

25. Neri, L. C. \& Johansen, H. L. (1978) Ann. N. Y. Acad. Sci. 304, 203-219.

26. Diem, K. \& Lentner, C., (1975) (èds.) Documenta Geigy, G. Thieme Verlag Stuttgart, $7^{\text {th }}$ edition, p. 521.

27. Seelig, M.S. (1981) Magnesium Bull. 3 (1a), 26-47.

28. Fehlinger, R., Franke, L., Glatzel, E., Meyer, E., Michalik, M., Rapoport, S. M., Rüstow, M., Schulz, C. \& Schumann, G. (1981) Magnesium Bull. 3, (1a), 298-306.

29. Anderson, T. W., Leriche, W. H., Hewitt, D. \& Neri, L. C. (1980) In: Magnesium in Health and Disease (Cantin, M. \& Seelig, M. S. eds.), Spektrum Publication, Inc. p. 565-571.

30. Ising, $H$., Günther, $T$., Handrock, M., Michalak, R., Schwarze, J., Vormann, J., \& Wüster, G. A. (1981) Magnesium Bull. 3 (1a), 155-164.

31. Günther, T., Ising, H. \& Merker, H. J. (1978) J. Clin. Chem. Clin. Biochem. 16, 293-297. polysis with trapping of $\mathrm{Mg}^{2+}$ in the adipocytes as $\mathrm{Mg}^{2+}$ soaps. To interrupt the vicious circle that complicates myocardial infarction and arrhythmias, it may be reasonable to supplement with $\mathrm{Mg}^{2+}$ in cases of hypomagnesaemia. For this purpose, intravenous administration of $\mathrm{Mg}^{2+}$ in saline (196) or, when used, in a glucose-insulin- $\mathrm{K}^{+}$-solution (93) has ben recommended.

32. Iseri, L. T., Alexander, L. C., McCaughey, R. S., Boyle, A. J. \& Myers, G. B. (1952) Am. Heart J. 43, 215-227.

33. Meister, H. \& Schumann, H. J. (1962) Beitr. Pathol. Anat. 126, 468-477.

34. Behr, G. \& Burton, P. (1973) Lancet II, 450

35. Chipperfield, B. \& Chipperfield, J. R. (1973), Lancet II, 293-297.

36. Anderson, T. W., Neri, L. C., Schreiber, G. B., Talbot, F. D. F. \& Zdrojewski, A. (1975) Can. Med. Assoc. J. 113, 199-203.

37. Chipperfield, B., Chipperfield, J. R., Behr, G. \& Burton, P. (1976) Lancet $I, 121-122$.

38. Brandt, G. \& Dörfelt, H. J. (1978) Krankenhausarzt 51 , 418-421.

39. Chipperfield, B. \& Chipperfield, J. R. (1978) Am. Heart J. 95, 732-737.

40. Johnson, C. J., Peterson, D. R. \& Smith, E. K. (1979) Am. J. Clin. Nutr. 32, 967-970

41. Elwood, P. C., Sweetnam, P. M., Beasley, W. H., Jones, D. \& France, R. (1980) Lancet II, 720-722.

42. Speich, M., Bousquet, B. \& Nicolas, G. (1980) Clin. Chem. 26, 1662-1665.

43. Lim, P. \& Jacob, E. (1972) Brit. Med. J. 3, 620-622.

44. Dyckner, T. \& Wester, P. O. Acta Med. Scand. 204, 269282.

45. Chipperfield, B. \& Chipperfield, J. R. (1979) Lancet II, 709-712.

46. Cummings, J. R. (1960) Circ. Res. 8, 865-870.

47. Sikka, K. K., Nath, K., Saxena, H., Sur, B. K. \& Dhingra, H. M. (1973) $1^{\text {st }}$ International Symposium on $\mathrm{Mg}$ Deficit in Human Pathol., Vittel, p. 347-349.

48. Cánepa, J. F. \& Gómez-Povina, O. A. (1965) J. Surg. Res. 8, 335-340.

49. Hochrein, H., Kuschke, H. J., Zaqqa, Q. \& Fahl, E. (1967) Klin. Wochenschr. 45, 1093-1103.

50. Shen, A. C. \& Jennings, R. B. (1972) Am. J. Pathol. 67, $417-440$

51. Jennings, R. B., Sommers, H. M., Kaltenbach, J. P. \& West, J. J. (1964) Circ. Res. 14, 260-269.

52. Burch, G. E., Lazarra, R. K. \& Yun, T. K. (1965) Proc. Soc. Exp. Biol. Med. 118, 581-584.

53. Günther, T., Merker, H. J., Nawroth, H., Ising, H., Lunkenheimer, P. P. \& Scharsich, M. (1981) Magnesium Bull. 3, 59-64.

54. Glaser, W. \& Brandt, J. L. (1959) Am. J. Physiol. 196, $375-376$.

55. Page, E. \& Polimeni, P. I. (1972) J. Physiol. 224, 121-139.

56. Watchorn, E. \& McCance, R. A. (1937) Biochem. J. 31, 1379-1390.

57. Martindale, L. \& Heaton, F. W. (1964) Biochem. J. 92, 119-126.

58. Günther, T. (1970) Z. Klin. Chem. Klin. Biochem. 8, 6568.

59. Hunt, B. J. (1971) Am. J. Physiol. 221, 1809-1817. 
60. George, G. A. \& Heaton, F. W. (1975) Biochem. J. 152, 609-615.

61. Heroux, O., Peter, D. \& Heggtveit, A. (1977) J. Nutr. 107, 1640-1652.

62. Laidig, A. \& Classen, H. G. (1980) Magnesium Bull. 2, 7275.

63. Stendig-Lindberg, G., Bergström, J. \& Hultman, E. (1977) Acta Med. Scand. 201, 273-280.

64. Ceremuzynski, L. (1981) Circ. Res. 48, 767-776.

65. Lehr, D., Krukowski, M. \& Colon, R. (1966) J. Am. Med. Assoc. 197, 145-151.

66. Kraikipanitch, S., Haygood, C. C., Baxter, D. J., Yunice, A. A. \& Lindeman, R. D. (1976) Am. Heart J. 92, 615622.

67. Abraham, A. S., Bar-On, E. \& Eylath, U. (1981) Medical Biol. 59, 99-102.

68. Vormann, J., Günther, T. \& Ising, H. (1981) Magnesium Bull. 3, 140-142.

69. Fleckenstein, A., Janke, J., Döring, H. J., Pachinger, O. (1974) in: Recent Advances in Studies on Cardiac Structure in Metabolism. (Bajusz, E., Rona, G., eds.) Urban \& Schwarzenberg, München - Wien - Berlin, p. 455-466.

70. Maguire, M. E. \& Erdos, J. J. (1980) J. Biol. Chem. 255, $1030-1035$.

71. Zimmer, H.-G. \& Gerlach, E. (1980) Arzneimittelforsch. 30, 2001-2007.

72. Mishra, R. K. (1960) Rev. Canad. Biol. 19, 175-180.

73. Vormann, J., Fischer, G., Thöni, H. \& Classen, H. G. (1983) Arzneimittelforsch. 73, 205-210.

74. Späh, F. \& Fleckenstein, A. (1979) J. Molec. Cell. Cardiol. $11,1109-1127$.

75. Kiyosue, T. \& Arita, M. (1982) Pflügers Arch. 395, 78-80.

76. Rinaldi, M. L., Le Peuch, C. J. \& Demaille, J. G. (1981) FEBS-Letters 129, 277-281.

77. Günther, T. (1981) Magnesium Bull. 3 (1a), 91-101.

78. Polimeni, P. I. \& Page, E. (1973) Circ. Res. 33, 367-374.

79. Wu, S. T., Pieper, G. M. Salhany, J.M. \& Eliot, R.S. (1981) Biochemistry 20, 7399-7403.

80. Hess, P. \& Weingart, R. (1981) J. Physiol. 318, 14 P.

81. Gupta, R. K. \& Yushok, W. D. (1980) Proc. Natl. Acad. Sci. USA 77, 2487-2491.

82. Nath, K., Sikka, K. K., Sur, B. K. Saxena, C. P. \& Srivastava, S. (1969) Ind. J. Med. Res. 57, 317-323.

83. Brown, D. F., McGandy, R. B., Gillie, E. \& Doyle, J. T. (1958) Lancet $I I, 933-935$.

84. Hughes, A. \& Tonks, R. S. (1965) Lancet $I, 1044-1046$.

85. Hyatt, K. H., Levy, L., Nichaman, M. \& Oscherwitz, M. (1966) Applied Spectroscopy 20,142-145

86. Abraham, A. S., Eylath, U., Weinstein, M. \& Czaczkes, E. (1977) New Engl. J. Med. 296, 862-863.

87. Lund, B., Badskjaer, J., Lund, B., Soerensen, O. H. (1978) Horm. Metab. Res. 10, 553-556.

88. Petersen, B., Christiansen, C. \& Transbøl, I. (1978) Dan. Med. Bull. 25, 116-118.

89. Gould, L., Reddy, C. V. R., Swamy, C. R. N., Oh, K. C. \& Kim, S. G. (1979) Angiology 30, 219-222.

90. Speich, M., Bousquet, B., Nicolas, G. \& de Lajatre, A. Y. (1979) Rev. Franc. Endocrinol. Clin. 20, 159-163.

91. Dyckner, T. (1980) Acta Med. Scand. 207, 59-66.

92. Zumkley, H., Vetter, H., Bertram, H. P., Tank, B. \& Wirth, W. (1980) Klin. Wochenschr. 58, 1143-1146.

93. Flink, E. B., Brick, J. E. \& Shane, S. R. (1981) Arch. Int. Med. $141,441-443$.

94. Rector, W. G., DeWood, M. A., Williams, R. V. \& Sullivan, J. F. (1981) Am. J. Med. Sci. 281, 25-29.

95. Roy, D. R. \& Seely, J. F. (1981) Am. J. Physiol. 240, F 17'F 24.

96. Lemann, J., Lennon, E. J., Piering, W. R., Prien, E. L. \& Ricanati, E. S. (1970) J. Lab. Clin. Med. 75, 578-585.

97. Lennon, E. J. \& Piering, W. F. (1970) J. Clin. Invest. 49, $1458-1465$.

98. McNair, P., Christensen, M. S., Christiansen, C., Madsbad, S. \& Transbøl, J. B. (1982) Europ. J. Clin. Invest. 12, 8185 .
99. Flink, E. B., Shane, S. R., Scobbo, R. R., Blechschmidt, N. G. \& McDowell, P. (1979) Metabolism 28, 858-865.

100. Rayssiguier, Y. (1977) Horm. Metab. Res. 9, 309-314.

101. Elliott, D. A. \& Rizack, M. A. (1973) J. Biol. Chem. 249, 3985-3990.

102. Vormann, J. Förster, R., Günther, T. \& Ebel, H. (1983) Magnesium Buli. (in press).

103. Burns, T. W. \& Langley, P. E. (1970) J. Lab. Clin. Med. 75 , 983-997.

104. Wenkeóva, J., Kuhn, E. \& Wenke, M. (1975) Europ. J. Pharmacol. 30, 49-55.

105. Burns, T. W. \& Langley, P. E. (1971) Pharmaçol. Res. Commun. 3, 271-277.

106. Burns, T.W., Mohs, J.M., Langley, P.E., Yawn, R. \& Chase, G. R. (1974) J. Clin. Invest. 53, 338-341.

107. Lafontan, M. \& Berlan, M. (1981) Int. J. Obesity 5, 65.1657.

108. Berlan, M. \& Lafontan, M. (1977) J. Physiol. (Paris) 73, 90A.

109. Gries, F. A. (1970) In: Adipose Tissue, Regulation and Metabolic Function (Jeanrenaud, B. \& Hepp, D., eds.) Georg Thieme Verlag Stuttgart, Acad. Press New York, London, 167-171.

110. Fain, J. N. (1967) Ann. N. Y. Acad. Sci. 139, 8799-890.

111. Rayssiguier, Y. \& Larvor, P. (1973) $1^{\text {st }}$ International Symposium on Magnesium, Vittel $479-484$.

112. Bajusz, E. \& Rona, G. (1972) In: Recent Advañces in Studies on Cardiac Structure and Metabolism, vol. 1 Myocardiology, Urbban \& Schwarzenberg, München.

113. Bajusz, E. \& Rona, G. (1974) In: Recent Advances in Studies on Cardiac Structure and Metabolism, vol. 2 Cardiomyopathies, Ứrban \& Schiwạizenberg, München.

114. Kaltenbach, M., Loogen, F. \& Olssèn, E. G. J. (1978) Cardiomyopathy and myocardial biopsy, Springer Verlag, Berlin.

115. Mendelson, J. H., Ogata, M. \& Mello, N. K. (1969) Ann. N. Y. Acad. Sci. $162,918-933$.

116. Rizek, J. E., Dimich, A. \& Wallach; S. (1965), J. Clin. Endocrinol. 25, 350-358.

117. Jones, J. E., Desper, P. C., Shạne, S. R. \& Flink, E. B. (1966) J. Clin. Invest. 45, 891-900.

118. Caddel, J. L. \& Goddard, D. R. (1967) New Engl. J. Med. $276,533-535$.

119. Lossnitzer, K. \& Bajusz, E. (1974) In: Recent Advances in Studies on Cardiac Structure and Metabolism (B̈ajusz, E. \& Röna, G., eds.) Vol. 2, 503-505.

120. Lossnitzer, K., Janke, J., Hein, B., Stauch, M. \& Fleckenstein, A. (1975) In: Recent Advances in Studies on Cardiac Structure and Metabolism (Fleckenstein, A. \& Rona, G., eds.) Vol. 6, 207-217.

121. Jasmin, G. \& Bajusz, E. (1975) In: Recent Advances in Studies on Cardiac Structure and Metabolism (Fleckensteiñ, A. \& Rona, G., eds.) Vol. 6, 219-229.

122. Lossnitzer, K., Konrad, A. \& Jacob, M. (1979) Magnesium Bull. 1, 149.

123. Wrogemann, K., Nylen, E. \& Blancaer, M. C. (1978) In: Recent Advañces in Studies on Cardiaç Structure and Metabolism (Kobayashi, T., Ito, Y. \& Ronà, G., eds.) Vol. 12, $351-357$.

124. Kaltenbach, M., Hopf, R. \& Keller, M. (1976) Dtșch. Med. Wochenschr. 101, 1284-1287.

125. Durham, A. C. H. (1978) Biomedicine 28, 307-314.

126. Farber, J. L. (1981) Life Sci. 29, 1289-1295.

127. Brown, B. G. (1981) Arch. Intern. Med. 141, 716-722.

128. Maseri, A. (1981) Am. J. Med. 70, 752-754.

129. Oliva, P. B. (1981) Ann. Intern. Med. 94, 236-250.

130. Frohlich, E. D., Scott, J. B. \& Haddy, F. J. (1962) Am. J. Physiol. 203, 583-587.

131. Haddy, F. J. (1960) Circ. Res. 8, 57-70.

132. Levowitz, B. S., Goldson, H., Rashkin, A., Kay, H., Valcin, A., Mathur, A. \& LaGuerre, J. N. (1970) Ann. Surg. 172, '33-40.

133. Scott, J. B., Frohlich, E. D., Hardin, R. A. \& Haddy, F. J. (1961) Am. J. Physiol. 201, 1095-1100. 


\begin{tabular}{|l|l}
\hline W & Walter de Gruyter \\
$\vdots$ & Berlin.New York
\end{tabular}

F. Lottspeich

A. Henschen

K.-P. Hupe

(Editors)

l. Molnar

(Editor)

\section{A. Henschen \\ H. Graeff \\ F. Lottspeich \\ (Editors)}

\section{Allen/Bienvenu/} Laurent/Suskind (Editors)
High Performance

Liquid Chromatography in Protein and Peptide Chemistry

Proceedings. International Symposium, January 1981,

Max-Planck-Institute for Biochemistry, Martinsried/Munich, Germany

$1982.17 \mathrm{~cm} \times 24 \mathrm{~cm}$. XVIII, 388 pages. Numerous illustrations. Hardcover. DM 145,-; approx. US \$69.25 ISBN 3110085429

Chromatography is one of the most versatile methods in modern biochemical and pharmacological work. The field is rapidly developing and the book is intended to be an up-to-date survey of the most recent developments of methods related to protein, peptide and amino acid analysis.

Practical Aspects of

Modern IPICC

Symposium, December 7-8, 1981, Berlin

$1982.17 \mathrm{~cm} \times 24 \mathrm{~cm}$. VIII, 449 pages. Numerous illustrations.

Hardcover. DM 170,-; approx. US \$81.00

ISBN 3110088924

\section{Fibrinogen}

Recent Biochemical and Medical Aspects Proceedings. International Symposium, February 17-18, 1981, Max-Planck-Institute for Biochemistry Martinsried/Munich, Germany

$1982.17 \mathrm{~cm} \times 24 \mathrm{~cm} . X, 400$ pages. Numerous illustrations. Hardcover. DM 135,-; approx. US $\$ 64.50$ ISBN 3110085437

\section{Marker Proteins in Inflammation Proceedings of the Symposium Lyon, France, April 22-25, 1981}

1982. $17 \mathrm{~cm} \times 24 \mathrm{~cm}$. XV, 608 pages. Numerous illustrations. Hardcover. DM 185,-; approx. US \$88.25 ISBN 3110086255 


\section{Walter de Gruyter Berlin-New York}

\section{K. Fotherby S. B. Pal} (Editors)
M. K. Agarwal (Editor)

\section{Hormones in Normal and . Abnormal Human Tissues}

\section{Volume 1}

$1980.17 \mathrm{~cm} \times 24 \mathrm{~cm}$. XIV, 658 pàges with figures and tables.

Hardcover. DM 145,-; approx. US \$69.25

ISBN 3110080311

\section{Volume 2}

$1981.17 \mathrm{~cm} \times 24 \mathrm{~cm}$. XII, 552 pages with figures and tables.

Hardcover. DM 135,-; approx. US $\$ 64.50$

ISBN 3110085410

\section{Volume 3}

$1982.17 \mathrm{~cm} \times 24 \mathrm{~cm}$. Approx. 500 pages with figurès and táblès.

Hardcover. Approx. DM 120,-; approx. US \$57.25

ISBN 3110086166

Hormones in Normal and Abnormal Human Tișsues is a threevolume monograph dealing with the circulating levels, the pathological and therapeutic conditions and the factors controlling the secretion of non-polypeptide, protein and steroid hormones.

An attempt has been made to place emphasis on the concentration of the various hormones in tissues; where they are produced and where they might localize and produce an effect, and how these levels are modified under various circumstances.

\section{Hormone Antagonists}

1982. $17 \mathrm{~cm} \times 24 \mathrm{~cm}$. IX, 734 pages. Numerous illustrations. Hardcover. DM 180,-; approx. US \$85.75 ISBN 3110086131

This book groups together under one single cover antagónists for those hormones where antagonism has been documented specifically and with a certain degree of certitude. The major emphasis has been delineation of anti-hormone activity at the level of the hormone receptor but other aspects, such as antibody mediated antagonism and inhibition of synthesis, have been included to indicate other possible levels of inhibition of hormone activity. Clinical aspects, too, have been covered where they were documented with certitude.

It is felt that the book represents a major new reference source for years to come. Scientists, medical academicians, and advanced graduate students may use the book as a departing: point for further pursuit of their own field. Involved research workers will find the volume of much interest since it provides data not published elsewhere. The book may also be used as a text volume to indicate the diversity and the wealth of information on the subject of hormone antagonism both in the basic research and in clinical medicine. Photo-offset method of publication assures expediency before specialized articles obsolete novelty. 
134. Texter, E. C., Laureta, H. C., Frohlich, E. D. \& Chou, C. C. (1967) Am. J. Physiol. 212, 569-573.

135. Dabney, J. M., Scott, J. B. \& Chou, C. C. (1967) Am. J. Physiol. 212, 835-839.

136. Chou, C. C. \& Emerson, T. E. (1968) Am. J. Physiol. 215, 1102-1106.

137. Haddy, F. J., Scott, J. B., Florio, M. A., Daugherty, R. M. \& Huizenga, J. N. (1963) Am. J. Physiol. 204, 202-212.

138. Anderson, D. K., Roth, S. A., Brace, R. A., Radawski, D., Haddy, F. J. \& Scott, J. B. (1972) Circ. Res. 31, 165-173.

139. Emerson, T. E., Scott, J. B. \& Haddy, F. J. (1970) Am. J. Physiol. 218, 234-240.

140. Altura, B. M. \& Altura, B. T. (1978) Blood Vessels 15, 5-16.

141. Altura, B. M. \& Altura, B. T. (1974) Microvasc. Res. 7, 145-155.

142. Altura, B. M. (1978) Artery 4, 512-527.

143. Turlapaty, P. D. M. V. \& Altura, B. M. (1980) Science 208, 198-200.

144. Altura, B. M. \& Altura, B. T. (1971) Am. J. Physiol. 220, 938-944.

145. Turlapaty, P. D. M. V. \& Altura, B. M. (1982) Basic Res. Cardiol. 77, 68-81.

146. Altura, B. M. \& Altura, B. T. (1977) Fed. Proc. 36, 18531860.

147. Altura, B. M. \& Altura, B. T. (1976) Proc. Soc. Exp. Biol. Med. 151, 752-755.

148. Carrier, O., Hester, R. K., Jurevics, H. A. \& Tenner, T. E. (1976) Blood Vessels 13, 321-337.

149. Turlapaty, P. D. M. V. \& Altura, B. M. (1978) Europ. J. Pharmacol. 52, 421-423.

150. Altura, B. M. (1979) Medical Hypothesis 5, 843-848.

151. Kruse, H. D., Orent, E. R. \& McCollum, E. V. (1932) J. Biol. Chem. 96, 519-539.

152. Greenberg, D. M. \& Tufts, E. V. (1938) Am. J. Physiol. $121,416-423$.

153. Mishra, R. K. (1960) Rev. Canad. Biol. 19, 122-135.

154. Samjowan, K. B., Rademeyer, L. J. \& Booyens, J. (1972) S. Afr. Med. J. 46, 215-221.

155. Syllm-Rapoport, I. (1962) J. Pediatr. 60, 801-804.

156. Wener, J., Pintar, K., Simon, M. A., Motola, R., Friedman; R., Mayman, A. \& Schucher, R. (1964) Am. Heart J. 67, $221-231$

157. Vitale, J. J., Hellerstein, E. E., Nakamura, M. \& Lown, B. (1961) Circ. Rès. 9, 387-394.

158. Seta, K., Kleiger, R., Hellerstein, E. E., Lown, B. \& Vitale, J. J. (1966) Am. J. Cardiol. 17, 516-519.

159. Grantham, J. J., Tu, W. H. \& Schloerb, P. R. (1960) Am. J. Physiol. 198, 1211-1216.

160. Seller, R. H., Cangiano, J., Kim, K. E., Mendelssohn, S., Brest, A. W. \& Swartz, C. (1970) Am. Heart J. 79, 57-68.

161. Tackett, R. L. \& Holl, J. E. (1981) J. Cardiovasc. Pharmacol. 3, 1269-1277.

162. Kleiger, R. E., Seta, K., Vitale, J, J. \& Lown, B. (1966) Am. J. Cardiol. 17, 520-527.

163. Ghani, M. F. \& Smith, J. R. (1974) Am. Hearit J. 88, 621626.

164. Specter, M. J., Schweizer, E. \& Goldman, R. H. (1975) Circulation $52,1.001-1005$.

i65. Vitale, J. J., Velez. H., Guzman, C. \& Correa, P. (1963) Circ. Res. 12, 642-650.
166. Kellaway, G. \& Ewen, K. (1962) N. Z. Med. J. 61, 137142.

167. Gerst, P. H., Porter, M. R. \& Fishman, R. A. (1964) Ann. Surg. 159, 402-406.

168. Loeb, H. S., Pietras, R. J., Gunnar, R. M. \& Tobin jr., J. R. (1968) Circulation 37, 210-215.

169. Ricketts, H. H., Denison, E. K. \& Haywood, L. J. (1969) J. Am. Med. Assoc. 207, 365-366.

170. Chadda, K. D., Lichstein, E. \& Gupta, P. (1973) Am. J. Cardiol. 31, 98-100.

171. McMullen, J. K. (1977) Brit. Med. J. 1, 690.

172. Klauser, H., Klauser-Reucker, C. \& Moccetti, T. (1977) Schweiz. Med. Wochenschr. 107, 1191-1195.

173. Shils, M. E. (1969) Medicine 48, 61-85.

174. Scheinman, M. M., Sullivan, R. W. \& Hyatt, K. H. (1969) Circulation 39/40, Suppl. 1, 235-241.

175. Rotman, L. (1981) Magnesium Bull. 3 (1a), 195-201.

176. Kim, Y. W., Andrews, C. E. \& Ruth, W. E. (1961) Am. J. Med. Sci. 242, 127-132.

177. Beller, G. A., Hood, W. B., Smith, T. W., Abelmann, W. H. \& Wacker, W. E. C. (1974) Am. J. Cardiol. 33, 225-229.

178. Singh, R. B., Dube, K. P. \& Srivastav, P. K. (1976) Am. Heart J. 92, 144-147.

179. Storstein, O., Hansteen, V., Hatle, L., Hillestad, L. \& Storstein, L. (1977) Am. Heart J. 93, 434-443.

180. Storstein, O., Hansteen, V., Hatle, L., Hillestad, L. \& Storstein L. (1977) Acta Med. Scand. 202, 445-447.

181. Holt, D. W. \& Goulding, R. (1975) Brit. Med. J. 1, 627628.

182. Fisher, J. \& Abrams, J. (1977) Arch. Intern. Med. 137, 1238-1241.

183. Flink, E. B., Stutzman, F. L., Anderson, A. R., Konig, T. \& Fraser, R. (1954) J. Lab. Clin. Med. 43, 169-183.

184. Fankushen, D., Raskin, D., Dimich, A. \& Wallach, S. (1964) Am. J. Med. 37, 802-812.

185. Härtel, G., Louhija, A. \& Konttinen, A. (1969) Acta Med. Scand. 185, 507-513.

186. Randall, R. E., Rossmeisl, E. C. \& Bleifer, K. H. (1959) Ann. Intern. Med. 50, 257-287.

187. Bajpai, P. C., Denton, R. L., Harpur, E., Stern, L. \& Sudgen, D. L. (1967) Can. Med. Assoc. J. 96, 148-153.

188. Bajpai, P. C., Sudgen, D., Stern, L. \& Denton, R. L. (1967) J. Pediatr. 70, 193-199.

189. Radde, J. C., Parkinson, D. K., Höffken, B., Appiah, K. E. \& Hanley, W. B. (1972) Pediatr. Res. 6, 43-49.

190. Friedman, Z., Hanley, W. B. \& Radde, J. C. (1972) Can. Med. Assoc. J. 107, 742-745.

191. Żwillinger, L. (1935) Klin. Wochenschr. 14, 1429-1433.

192. Enselberg, C. D., Simmons, H. G. \& Mintz, A. A. (1950) Am. Heart J. 39, 703-712.

193. Szekely, P. \& Wynne, N. A. (1951) Clin. Sci. 10, 241-247.

194. Harris, A. S., Estandia, A., Smith, H. T., Olson, R. W., Ford, T. J. and Tillotson, R. F. (1953) Am. J. Physiol. 172. 251-258.

195. Dyckner, T. \& Wester, P. O. (1979) Am. Heart J. 97, 1218.

196. Morton, B. C., Smith, F. M., McKibbon, T. J., Nair, C. \& Poznanski, W. J. (1981) Magnesium Bull. 3 (1a), 192-194.

Prof. Dr. H. Ebel

Institut für Klinische Physiologie

im Klinikum Steglitz

Frẹie Universität Berlin

Hindenburgdamm 30

D-1000 Berlin 45 
